\title{
Immunoaffinity purification of a [U4/U6.U5] tri-snRNP from human cells
}

\author{
Sven-Erik Behrens and Reinhard Lührmann \\ Institut für Molekularbiologie und Tumorforschung, D-3550 Marburg, Germany
}

\begin{abstract}
We describe the isolation and biochemical characterization of [U4/U6.U5] tri-snRNP complexes from HeLa cells under nondenaturing conditions using a monoclonal antibody reacting with the U5-specific 100-kD protein. We show that the [U4/U6.U5] complex contains five previously unobserved proteins with molecular masses of $90,60,27,20$, and $15.5 \mathrm{kD}$, in addition to the core proteins, common to the U4/U6, U5, U1, and U2 snRNPs, and the U5-specific proteins, as found in 20S U5 snRNPs. With $\sim 20$ distinct snRNP proteins the complexity of the [U4/U6.U5] tri-snRNP is surprising. One or more of the five proteins found exclusively in the 25S [U4/U6.U5] tri-snRNP appears to be involved in the assembly of the tri-snRNP complex, as, in an in vitro reconstitution assay, purified $20 \mathrm{~S} \mathrm{U} 5$ and $10 \mathrm{~S} \mathrm{U} 4 / \mathrm{U} 6 \mathrm{snRNPs}$ formed stable $25 \mathrm{~S}$ [U4/U6.U5] complexes only in the presence of the free tri-snRNP-specific proteins. The formation of the [U4/U6.U5] complex in vitro does not require ATP, and the stability of the purified tri-snRNP complex is not affected by ATP to a measurable extent. However, the native [U4/U6.U5] displays a kinase activity that is absent in isolated U5: A 52-kD protein present in both U5 and [U4/U6.U5] is phosphorylated only in the latter. The function of this phosphorylation is unclear thus far; it may be involved in the activation of [U4/U6.U5] in the spliceosome.
\end{abstract}

[Key words: Splicing; [U4/U6.U5] tri-snRNP complex; snRNP proteins; ATPase]

Received February 11, 1991; revised version accepted April 29, 1991.

Splicing of nuclear mRNA precursors (pre-mRNA) is known to take place in a two-step mechanism that requires ATP. During the splicing process, several interacting species, including the pre-mRNA, are assembled in a highly organized process to form the so-called spliceosome (for review, see Green 1986; Padgett et al. 1986; Sharp 1987; Guthrie and Patterson 1988).

The best-characterized components of the spliceosome are the small nuclear ribonucleoprotein particles (snRNPs) U1, U2, U4/U6, and U5, which are essential snRNP participants in the splicing process. The four snRNPs are distinct in both their RNA (called snRNA) and protein composition. Although U1, U2, and U5 snRNPs contain U1, U2, and U5 snRNAs, respectively, the snRNP U4/U6 contains two different RNA species, U4 and U6 (for review, see Maniatis and Reed 1987; Steitz et al. 1988).

The proteins of mammalian snRNPs can be classified into two kinds: (1) common proteins (i.e., those common to all particles), designated $\mathrm{B}, \mathrm{B}^{\prime}, \mathrm{D} 1, \mathrm{D} 2, \mathrm{D} 3, \mathrm{E}, \mathrm{F}$, and $\mathrm{G}$ (Bringmann and Lührmann 1986; Lehmeier et al. 1990; for review, see Lührmann 1988; Lührmann et al. 1990); and (2) specific proteins, which are found associated with only one type of snRNP. U1 snRNPs possess the specific proteins $70 \mathrm{~K}, \mathrm{~A}$, and $\mathrm{C}$, whereas $\mathrm{U} 2$ snRNPs possess the proteins $\mathrm{A}^{\prime}$ and $\mathrm{B}^{\prime \prime}$. U5 snRNPs possess at least eight specific proteins with molecular masses of 200 (a double band), 116, 102, 100, 52, 40, and $15 \mathrm{kD}$ (Bach et al. 1989). The complete U5 has a Svedberg value of 20 , but a $10 \mathrm{~S}$ form, which contains only the common snRNP proteins, can also be isolated (Bach et al. 1990). In yeast, only one U5-specific protein has been detected thus far. It is termed PRP8 and has a molecular mass of $260 \mathrm{kD}$ (Lossky et al. 1987; Jackson et al. 1988). Although proteins specific to U4/U6 snRNPs have not yet been identified in metazoan cells, the yeast U4/U6 snRNP contains a 52-kD protein denoted PRP4 (Bjorn et al. 1989; Banroques and Abelson 1990).

Spliceosome assembly involves dynamic interactions between the different snRNPs and also between snRNPs and the pre-mRNA. The latter requires specific signal sequences, such as the $5^{\prime}$ - and $3^{\prime}$-splice sites and the branchpoint region (for review, see Guthrie and Patterson 1988; Steitz et al. 1988).

$\mathrm{U} 1$ and U2 snRNPs bind to the $5^{\prime}$-splice site and the branchpoint, respectively. The interaction of $\mathrm{U} 1$ and $\mathrm{U} 2$ with the pre-mRNA is known to involve base-pairing between the snRNA and the pre-mRNA (Mount et al. 1983; Krämer et al. 1984; Zhang and Weiner 1986, 1989; Parker et al. 1987; Seraphin et al. 1988; Siliciano and Guthrie 1988; Wu and Manley 1989), supported by the interaction of specific proteins (Ruskin et al. 1988; Heinrich et al. 1990). After the binding of U1 and U2 snRNPs, the U4/U6 and U5 snRNPs assemble onto the premRNA in an ATP-dependent reaction (Bindereif and Green 1987; Ruby and Abelson 1989). These two snRNPs appear to join the spliceosome at the same time (Bindereif and Green 1987; Cheng and Abelson 1987; Ko- 
narska and Sharp 1987). However, little is known about the nature of the interaction of U4/U6 and U5 with the presplicing complex, except for some evidence that protein-RNA interactions may be involved in the interaction between U5 and the pre-mRNA substrate (Chabot et al. 1985; Gehrke and Steitz 1986; Tazi et al. 1986; Garcia-Blanco et al. 1990). Only after the integration of U4/ U6 and U5 is the spliceosome functionally complete.

Only recently has information regarding the function of U4/U6 and U5 snRNPs in splicing begun to emerge. The U5 particle has been shown to enhance the first step of splicing and to be essential for the second step (Patterson and Guthrie 1987; Winkelmann et al. 1989). It appears that the U4/U6 particle may play a central role in splicing. U4 and U6 snRNA interact by extensive basepairing (Bringmann et al. 1984; Hashimoto and Steitz 1984; Rinke et al. 1985; Brow and Guthrie 1988), in which two intermolecular helices (stems I and II), separated by an intramolecular stem-loop in $U 4$, give rise to a Y-shaped domain that is phylogenetically highly conserved (Brow and Guthrie 1988; Guthrie and Patterson 1988; Zucker-Aprison et al. 1988). It is probable that the transition to the active form of the spliceosome is accompanied by the dissociation of $U 4$, or at least a substantial conformational rearrangement within the U4/ U6 interaction domain (Pikielny et al. 1986; Cheng and Abelson 1987; Lamond et al. 1988; Blencowe et al. 1989). It has been proposed that the highly conserved U6 snRNA plays a catalytic role in the splicing reaction, and the task of $U 4$ may be to regulate this process (Brow and Guthrie 1989; Guthrie 1989; Fabrizio and Abelson 1990).

However, the participation of U4/U6 or U5 snRNPs in the splicing process should not be considered separately. There is evidence that U4/U6 and U5 snRNPs form a tri-snRNP complex in both mammals and yeast (Cheng and Abelson 1987; Konarska and Sharp 1987). In glycerol gradients of HeLa cell nuclear extracts or yeast cell lysates, U4, U5, and U6 cosediment with a Svedberg value of 25 (Konarska and Sharp 1987; Black and Pinto 1989; Bordonné et al. 1990|. Antibodies against the U5-specific yeast protein PRP8 precipitate both U4 and U6 (Lossky et al. 1987). Conversely, antibodies against PRP4 (a U4/ U6-specific protein) also precipitate U5 snRNPs (Banroques and Abelson 1989; Bjorn et al. 1989). In both mammalian and yeast systems, however, little is known about the structure-function relationship of this [U4/ U6.U5] complex. For example, it is unclear whether the various U5-specific proteins found in purified 20S U5 snRNPs are also present in the [U4/U6.U5] complex and, more important, whether additional proteins are needed for stable interaction between U4/U6 and U5. Another question of interest is the role of ATP in the associationdissociation equilibrium of the [U4/U6.U5] complex. Depletion of ATP from HeLa nuclear extracts appears to inhibit the formation of the [U4/U6.U5] complex (Black and Pinto 1989/. In yeast extracts, both stimulatory and inhibitory effects of ATP on the formation of the trisnRNP complex have been reported (Lossky et al. 1987; Bordonné et al. 1990).

Here, we report the purification, under native condi- tions, of [U4/U6.U5] complexes from HeLa cell nuclear extracts. We show that the $25 \mathrm{~S}$ tri-snRNP complex contains previously unobserved proteins that are stably bound at low ionic strength. These proteins appear to be necessary for the association of U5 and U4/U6 snRNPs, as purified $20 \mathrm{~S}$ U5 and 10S U4/U6 snRNPs form stable [U4/U6.U5] tri-snRNP complexes in vitro only in the presence of the free tri-snRNP-specific proteins. We detect an ATP-dependent kinase activity in the [U4/ U6.U5] complex that selectively phosphorylates a $52-\mathrm{kD}$ protein present in both U5 and [U4/U6.U5]. The association-dissociation equilibrium of the purified [U4/ U6.U5] tri-snRNP complex, however, is not affected by ATP.

\section{Results}

Purified 20 S U5 snRNPs and 10S U4/U6 snRNPS are unable to form a stable [U4/U6.U5] complex

As a first step, we investigated whether U5 and U4/U6 snRNPs purified by anti- $m_{3} G$ immunoaffinity chromatography at high salt concentrations, and thus well defined with regard to their components, are able to form complexes with one another in vitro. Under these conditions, U5 snRNPs contain the common proteins and also eight specific proteins, whereas U4/U6 snRNPs contain only the common proteins (Bringmann et al. 1984; Bach et al. 1989|. For this purpose, we compared, by fractionation in glycerol gradients, the snRNPs in HeLa nuclear splicing extracts with isolated snRNPs that were eluted from an anti- $m_{3} G$ column under high salt conditions $(420 \mathrm{mM} \mathrm{NaCl})$ and then dialyzed to $150 \mathrm{~mm} \mathrm{KCl}$. Figure 1 shows the distribution of snRNA throughout such a gradient. In HeLa nuclear splicing extracts, the majority of U4/U6 and U5 snRNPs cosediment at $25 \mathrm{~S}$ (Fig. 1A), as has been described previously (Konarska and Sharp 1987; Black and Pinto 1989). Although a fraction of U1 and U2 snRNPs smear over the entire gradient, the majority of $\mathrm{U} 2$ now sediments in the $15 \mathrm{~S}-18 \mathrm{~S}$ region and U1 is found predominantly at 10S-12S. The sedimentation pattern of the purified snRNPs differs considerably from that observed with nuclear splicing extracts (Fig. 1B). It should be noted that a high proportion of the U5 particles $(>80 \%)$ are present in the $20 \mathrm{~S}$ form. These particles are well separated from the more abundant $U 1$ and U2 snRNPs. At 25S, where any assembled [U4/U6.U5] complex would be expected, only trace quantities of U5 and $U 4 / \mathrm{U} 6$, as well as U1, are observed that smear over the entire gradient. If the dialyzed snRNPs are incubated with ATP before centrifugation, no difference is observed in the patterns of migration or association /data not shown). These data indicate that the U5 and U4/U6 snRNPs, after high salt anti- $\mathrm{m}_{3} \mathrm{G}$ immunoaffinity chromatography, are unable to form a [U4/U6.U5] complex efficiently. The simplest explanation for this behavior is that in addition to the known components of U5 and U4/U6, additional proteins are needed for complex formation but dissociate from the U5 and/or the U4/U6 particles under the high salt conditions of anti- $\mathrm{m}_{3} \mathrm{G}$ immunoaffinity chromatography. 


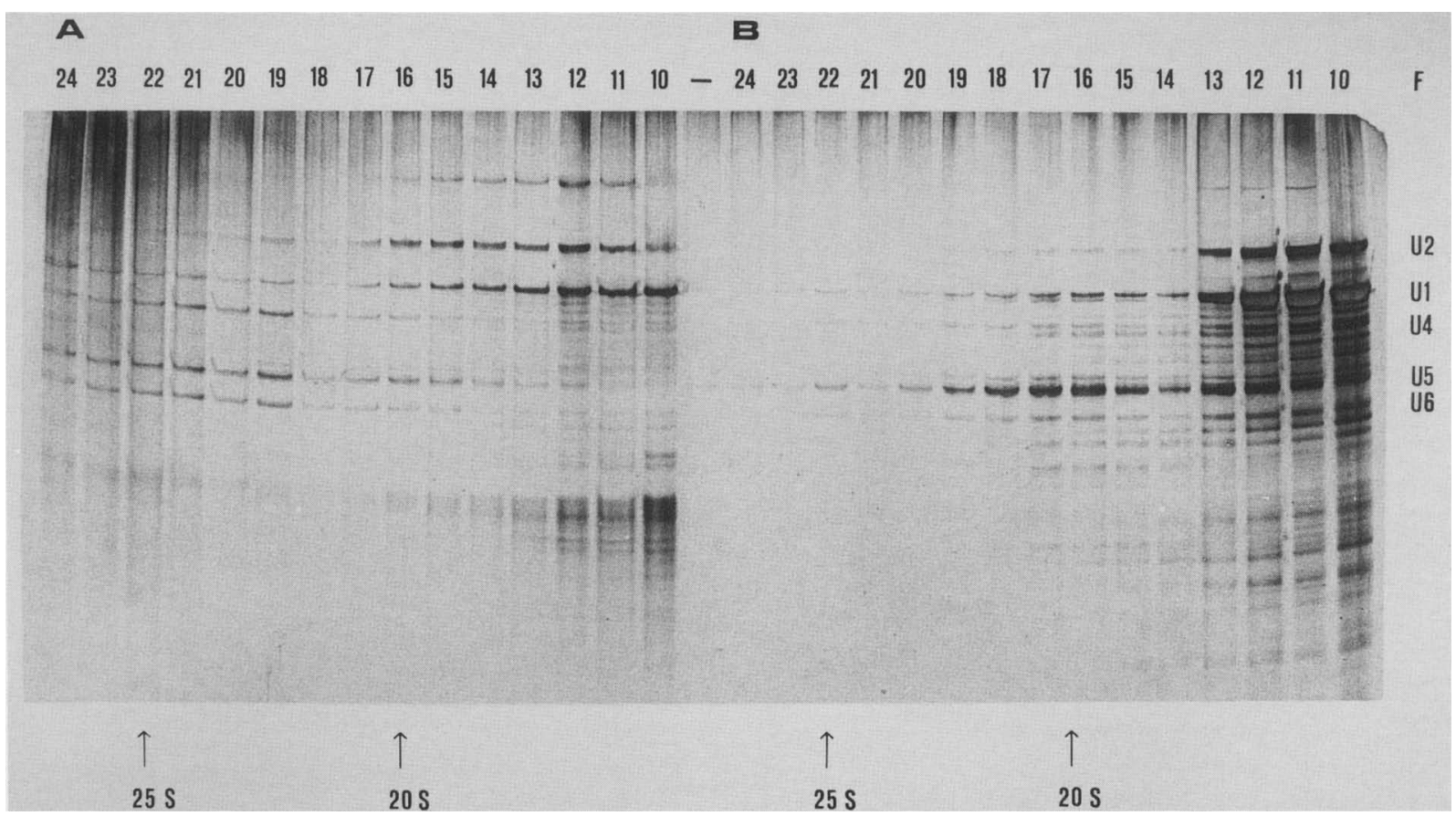

Figure 1. Association behavior of anti- $\mathrm{m}_{3} \mathrm{G}$ immunoaffinity-purified Ul-U6 snRNPs in comparison with snRNPs in nuclear extracts as determined by density gradient centrifugation. Two and one-half milliliters of a splicing-active nuclear extract (containing $150 \mathrm{mM}$ $\mathrm{KCl})(A)$ or $500 \mu \mathrm{g}$ of snRNPs desorbed from an anti- $\mathrm{m}_{3} \mathrm{G}$ immunoaffinity column at $420 \mathrm{mM} \mathrm{NaCl}$ and dialyzed to splicing-extract conditions $(150 \mathrm{mM} \mathrm{KCl})(B)$ were subjected to glycerol gradient centrifugation. Centrifugation was performed on $10-30 \%$ gradients as described in Materials and methods. Fractions of $500 \mu \mathrm{l}$ were harvested from top to bottom. RNAs from $100 \mu \mathrm{l}$ of each fraction were extracted and separated by electrophoresis on a $10 \%$ polyacrylamide gel containing $8 \mathrm{~m}$ urea and visualized by silver staining. $(A)$ The RNA pattern of density-fractionated nuclear extract; $(B)$ the RNA pattern of the density-fractionated anti-m $m_{3} G$-purified snRNPs.

The monoclonal antibody $H 386$ cross-reacts with the U5-specific 100-kD protein and precipitates $20 \mathrm{~S}$ U5 snRNPs as well as 25S [U4/U6.U5] tri-snRNP complexes

The above result prompted the isolation of native [U4/ U6.U5] complexes from nuclear splicing extracts to investigate whether the native tri-snRNP complex contains proteins absent from purified 20S U5 and 10S U4/ U6 snRNPs. Purification of the [U4/U6.U5] tri-snRNP complex was made possible by the chance observation that the monoclonal antibody $\mathrm{H} 386$ not only reacts with the U1-specific 70K protein, against which it was originally raised (Reuter et al. 1986), but also strongly crossreacts with the U5-specific $100-\mathrm{kD}$ protein. This is demonstrated by the immunoblot and ELISA data shown in Figure 2 . When total proteins from anti- $\mathrm{m}_{3} \mathrm{G}$ immunoaffinity-purified U1-U6 snRNPs were reacted on Western blots with $\mathrm{mAb} \mathrm{H386,} \mathrm{a} \mathrm{strong} \mathrm{reaction} \mathrm{was} \mathrm{observed}$ with a protein corresponding to $\sim 100-\mathrm{kD}$ molecular mass, in addition to the U1-70K protein (Fig. 2A). In the $100-\mathrm{kD}$ region, three proteins specific for U5 with molecular masses of 100,102 , and $116 \mathrm{kD}$ are found. When an ELISA assay was carried out with purified individual U5-specific high-molecular-weight proteins, it became clear that only the $100-\mathrm{kD}$ protein reacted with $\mathrm{H} 386$ (Fig. 2B).
H386 not only reacts with the denatured U5-specific $100-\mathrm{kD}$ protein, but also when this protein is present in the isolated, complete 20S U5 snRNP particle, as shown by immunoprecipitation. Initial precipitation experiments were carried out with FPLC-purified particles, and immune-precipitated RNAs were identified by labeling the RNA $3^{\prime}$ termini with ${ }^{32} \mathrm{pCp}$ by T4 RNA ligase. As Figure 3 shows, H386 not only precipitates purified U1 snRNPs, but also 20 S U5 snRNPs. Precipitation did not occur with 10S U5 snRNPs (Fig. 3) or with U2 snRNPs (the latter not shown). As a control, an additional 70Kspecific monoclonal antibody, $\mathrm{H} 111$, reacting with a $70 \mathrm{~K}$ epitope distinct from that of $\mathrm{H} 386$, was also used. $\mathrm{H} 111$ precipitates only U1 snRNPs, and not 20S U5 snRNPs (Fig. 3). Specific immunoprecipitation of 20S U5 snRNPs with $\mathrm{mAB} \mathrm{H} 386$ occurred only when the ionic conditions of the reaction and the subsequent washing steps were carried out under low salt concentrations (150 mM) and no detergent was present.

Finally, we investigated whether $\mathrm{H} 386$ is also able to precipitate the native [U4/U6.U5] complex from splicing-active HeLa nuclear extract. For this purpose, splicing extracts were fractionated on glycerol gradients, as in Figure 1A, and immunoprecipitations were carried out with fractions 20-23 of the gradient that correspond to the $25 \mathrm{~S}$ region. These fractions also contain small quantities of U1 and U2. 
A

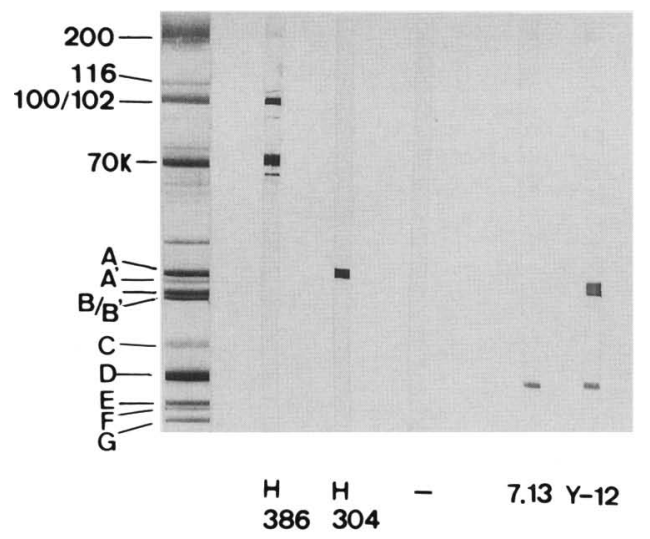

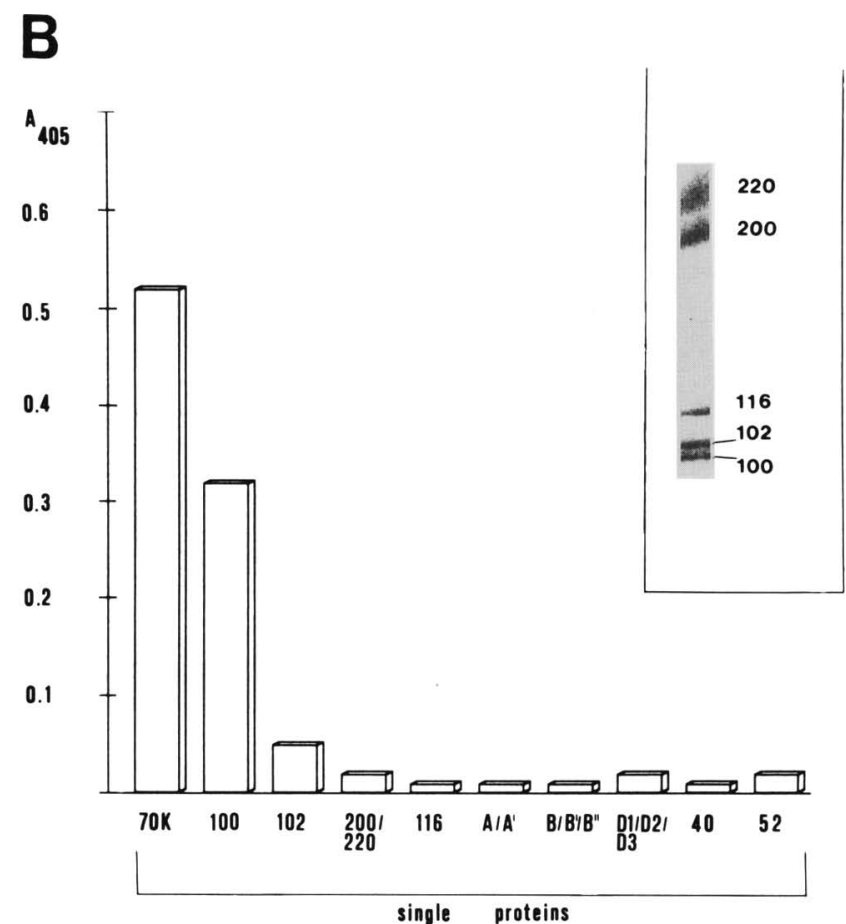

Figure 2. Characterization of the binding properties of mAb H386. (A) Cross-reactivity of mAB H386 with Ul-70K and a U5-specific protein. Blotting was carried out as described in Materials and methods. (Left lane) The pattern of snRNP proteins, separated on a 5-20\% SDS-polyacrylamide gel, before transfer to nitrocellulose. Principal snRNP proteins are indicated. (H386) Previously believed to be specific against the U1-70K protein. (H304) Control monoclonal antibody, specific for the A protein (Reuter and Lührmann 1986). (7.13) Control monoclonal antibody, specific for the D1 protein (Billings et al. 1985). (Y-12) Control monoclonal antibody, anti-Sm (Lerner et al. 1981), which reacts with B/B' and D. (Center lane) As a negative control, mAb C383, directed against a ribosomal protein (Schwedler-Breitenreuter et al. 1986), was used. (B) Assay of reactivity of mAb H386 with individual snRNP proteins by ELISA. The microtiter ELISA with mAb H386 using various electroeluted single snRNF proteins as antigenic material, was performed as described in Materials and methods. In the histogram, the averages of eight separate phosphatase activity assays indicated by the amount of material antibodies at $405 \mathrm{~nm}$ are shown (s.D. ranges from 5-10\%). The inset shows the separation of the high-molecular-weight snRNP proteins on a 5-8\% SDS-polyacrylamide gradient gel, allowing the separation of the 100- and 102-kD proteins.

Figure 3 (lanes $8-10$ ) shows that $\mathrm{H} 386$ not only precipitates U5 RNA, but also U4 and U6 RNA, from the 25S fractions. It should be noted that the relative abundance and molar ratio of snRNAs present in the immune precipitate cannot be estimated using the postlabeling procedure, owing to significant differences in the labeling efficiency of the $3^{\prime}$ end of the snRNAs. U6 RNA, for example, is labeled with pCp at very low efficiency as compared with the other snRNAs. The Ul snRNPs sedimenting in these fractions are also precipitated by H386. In contrast, precipitation of the U2 snRNPs, which are present in these fractions in varying amounts, is never observed. If precipitation of these fractions is carried out with the antibody $\mathrm{H} 111$, which reacts exclusively with U1, no U4, U5, or U6 is detected in the precipitate (Fig. 3, lane 11). These results indicate that H386 precipitates $\mathrm{U} 4, \mathrm{U} 5$, and $\mathrm{U} 6$ as a single complex and reacts with $U 1$ in an independent manner (see also below).

Isolation of native [U4/U6.U5] complex by immunoaffinity chromatography with H386

The efficient immunoprecipitation of [U4/U6.U5] complexes from gradient-fractionated nuclear extracts (Fig. 3) suggested that $\mathrm{H} 386$ could be used preparatively. Therefore, we set out to establish conditions that allow the preparation of this complex in its native form. From separate experiments on epitope mapping (Netter et al. 1991; S.-E. Behrens and R. Lührmann, unpubl.) we were already aware that $\mathrm{H} 386$ recognizes two independent domains on the U1-specific $70 \mathrm{~K}$ protein that contain similar amino acid sequences (residues 373-436 and 526557; numbering according to Theissen et al. 1986). Therefore, a polypeptide, 32 amino acids in length, whose sequence corresponds exactly to the second of these domains and thus contains an H386 epitope, was synthesized. By immunoprecipitation experiments we were able to verify that an excess of the synthetic peptide inhibits the binding, and thus also the precipitation, of both purified U5 snRNPs and [U4/U6.U5] (data not shown). These results indicated that this peptide could be used to desorb [U4/U6.U5] bound to immobilized $\mathrm{H} 386$ on an immunoaffinity column.

As starting material for the preparation of the $25 \mathrm{~S}$ [U4/ U6.U5] complex, the appropriate fractions from glycerol density gradients of HeLa nuclear extracts were used (e.g., see Fig. 1A, lanes 20-23). Figure 4A shows the RNA 


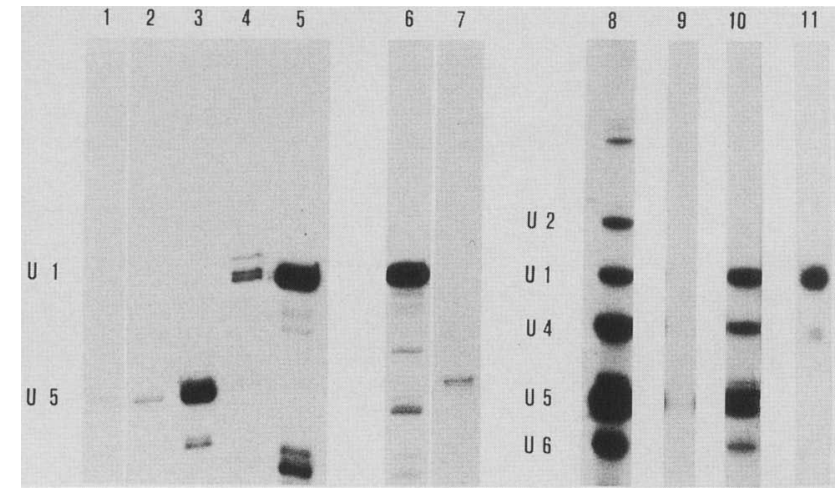

Figure 3. Immunoprecipitation assay of purified snRNPs with $\mathrm{mAb} \mathrm{H} 386$ and $\mathrm{mAb} \mathrm{H} 111$. Immunoprecipitation assays were carried out as described in Materials and methods. An autoradiograph of the gel-fractionated (10\% polyacrylamide, $8 \mathrm{M}$ urea) $\left[{ }^{32}\right]$ pCp-labeled snRNAs from the various immunoprecipitates is shown. mAb H386 and mAb H111, both directed against the U1-specific 70K protein (Reuter and Lührmann 1986), are compared with respect to their ability to precipitate 20 S U5 snRNPs or $25 \mathrm{~S}$ [U4/U6.U5] tri-snRNPs. The non-snRNP-specific mAb C383 (see above) was used as a control. In lanes 1-7 the reactivity of the monoclonal antibodies with various snRNP monoparticles, purified by Mono-Q chromatography $(\sim 2 \mu \mathrm{g}$ was used per assay), is shown. (Lane 1) Precipitate of 20S U5 snRNPs with mAb C383; (lane 2) 10S U5 snRNPs/mAb H386; (lane 3) 20S U5 snRNPs/mAb H386; (lane 4) U1 snRNPs/mAb C383; (lane 5) U1 snRNPs/mAb H386; (lane 6) U1 snRNPs/mAb H111; (lane 7) $20 \mathrm{~S}$ U5 snRNPs/mAb H111. In lanes $8-11$ the reactivity of the monoclonal antibodies with $25 \mathrm{~S}$ [U4/U6.U5] complexes is shown. One hundred-microliter aliquots of the $25 \mathrm{~S}$ fractions from glycerol gradient-fractionated nuclear splicing extracts (pooled fractions 21 and 22; cf. Fig. 1A) were used for each assay. (Lane 8 ) The total RNA composition of a 100- $\mu$ l aliquot of the pooled fractions 21 and 22; (lane 9) precipitate of mAb C383; (lane 10) precipitate of $\mathrm{mAb} \mathrm{H386;} \mathrm{(lane} \mathrm{11)} \mathrm{precipitate} \mathrm{of} \mathrm{mAb}$ H111.

analysis of a typical immunoaffinity chromatography with the H386 affinity column after elution with the synthetic peptide. Under standard conditions $(150 \mathrm{~mm}$ $\mathrm{KCl}$ ), the column retained U1, U4/U6, and U5 snRNPs, whereas the RNA present in the flowthrough was almost exclusively U2 or unrelated RNA (data not shown). Upon application of the peptide, $>80 \%$ of the U1, U4/ U6, and U5 was desorbed and emerged from the column as a sharp peak in four to five fractions (Fig. 4A, lanes 3-6). The snRNPs obtained in this way are virtually uncontaminated with RNA of higher or lower molecular weight (Fig. 4A).

To substantiate our supposition that the U4/U6 snRNP is an integral component of a [U4/U6.U5] complex when it is retained on, and eluted from, the H386 column, the peptide eluate from the H386 column was subjected to glycerol gradient centrifugation. The RNA analysis of such a gradient shows (Fig. 4B) that the snRNPs U4/U6 and U5 comigrate with a sedimentation coefficient of 25 . This finding clearly demonstrates that a stable [U4/U6.U5] complex has been isolated. The U1
snRNPs coeluted from the $\mathrm{H} 386$ affinity column migrate in the glycerol gradient with a value of $10 \mathrm{~S}-12 \mathrm{~S}$. When the intensities of the silver-stained RNA bands are compared (Fig. 4B), it is apparent that the amounts of U4, U5, and U6 snRNA in fractions 19-22 are about equal.

\section{The protein composition of the isolated [U4/U6.U5] complex}

When the protein pattern of the 20S U5 snRNPs (Fig. 5A, lane 3) is compared with that of the [U4/U6.U5] complex purified by immunoaffinity chromatography followed by glycerol gradient centrifugation (Fig. 5A, lanes 1 and 2), a number of previously unobserved protein components can be identified in the latter complex. In addition to the common and U5-specific proteins, at least five additional tri-snRNP-specific proteins with molecular masses of 90, 60 (frequently running as double or triple band), 27,20 , and $15.5 \mathrm{kD}$ are reproducibly observed.

The $27-\mathrm{kD}$ protein is clearly found more frequently in the $25 \mathrm{~S}$ fraction but is also present, although in low amount, in the upper part of the gradient (not shown), suggesting a more labile association. All of these proteins can be detected by Coomassie blue staining in the original coeluate containing U1 snRNPs (not shown).

\section{Detection of an ATP-specific kinase activity in isolated [U4/U6.U5] tri-snRNP complexes}

Several studies have revealed evidence of an important role of ATP in the morphogenesis of the multiple snRNP [U4/U6.U5] complex and possibly also in the structural alterations that take place within the spliceosome (see introductory section). As a first step in investigating the role of ATP in the function of [U4/U6.U5] as a splicing factor, we have looked for the phosphorylation of U4/ U5/U6 proteins in vitro. For this purpose, [U4/U6.U5] complexes purified on a glycerol gradient were incubated with $\left[\gamma^{-32}\right.$ P]ATP in vitro. SDS-polyacrylamide gel electrophoresis of the proteins with subsequent autoradiography showed that one protein is selectively phosphorylated (Fig. 5B, lane 1). This phosphorylated protein shows a molecular mass of $52 \mathrm{kD}$ and is in all probability the $52-\mathrm{kD}$ protein characterized as a specific component of the 20S U5 snRNP. This is seen clearly by comparing Figure 5B with the protein patterns in Figure 5A, lanes $1-3$. The phosphorylation is strictly ATP-dependent, and GTP is not accepted as a donor (Fig. 5B, lane 2). It is also interesting that the incubation of isolated $20 \mathrm{~S}$ U5 snRNPs with ATP does not lead to the phosphorylation of the $52-\mathrm{kD}$ protein (Fig. 5B, lane 4). These data demonstrate that only the [U4/U6.U5] tri-snRNP complex contains the phosphokinase activity that leads to ATPdependent phosphorylation of the $52-\mathrm{kD}$ protein in vitro.

When the kinase activity was measured across the glycerol gradient, used for the final purification step of the [U4/U6.U5] complex, phosphorylation of the $52-\mathrm{kD}$ protein was only observed in the $25 \mathrm{~S}$ region of the gradient regardless of whether purified 20 S U5 snRNPs 
Figure 4. RNA profiles of Ul snRNPs and [U4/U6.U5] tri-snRNPs eluted from the H386 immunoaffinity column. (A) Elution profile of the snRNPs. The immunoaffinity purification was carried out with $\mathrm{H} 386$ as described in Materials and methods. The snRNPs were eluted at $10 \mu \mathrm{M}$ competing peptide, collected in $300-\mu l$ fractions, and analyzed for RNA composition. In all, 15 fractions were obtained, and the peak is seen clearly in fractions 3-6. RNA was separated on a $10 \%$ polyacrylamide gel containing $8 \mathrm{M}$ urea and stained with silver. An aliquot of snRNPs not subjected to immunoaffinity purification was used as a marker. (B) Separation of the coeluted Ul snRNPs from the [U4/U6.U5] tri-snRNP complex by glycerol density gradient centrifugation. Fractions obtained by H386 immunoaffinity chromatography containing the snRNP peak were subjected to density gradient centrifugation, performed under conditions identical to those described in Figure 1. The RNAs from a 100- $\mu$ l aliquot of each $500-\mu$ l fraction were analyzed in the manner described above.

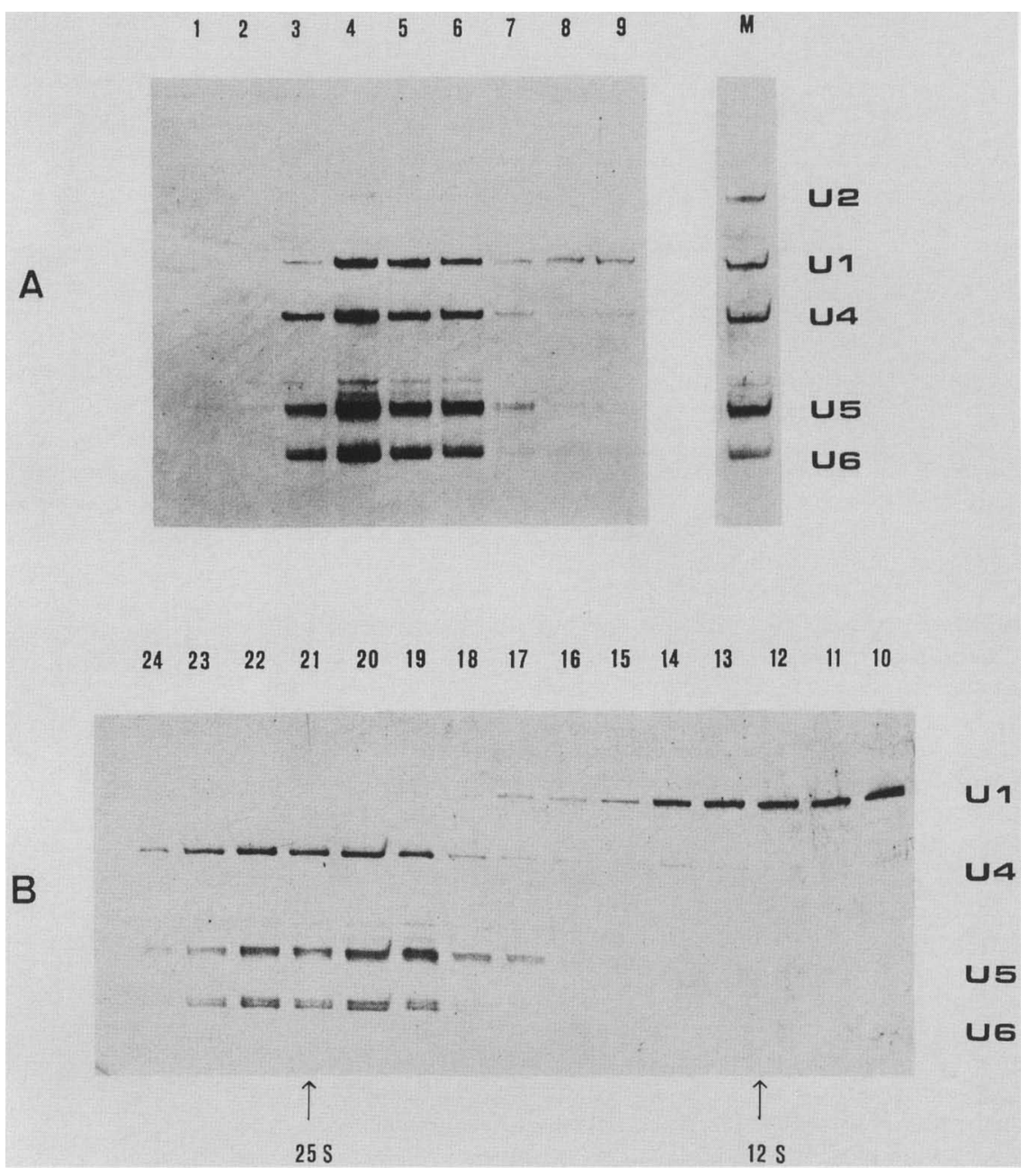

were added to the gradient fractions as an exogeneous substrate or not (not shown). This indicates that the kinase activity cosediments with the [U4/U6.U5] trisnRNP.

Evidence that the [U4/U6.U5] tri-snRNP-specific proteins are required for stable $25 \mathrm{~S}$ complex formation

The presence of five proteins in the isolated $25 \mathrm{~S}$ trisnRNP complex, which have not been detected previously in the purified individual snRNPs, suggested that these proteins are important for the formation of the [U4/U6.U5] complex. To obtain more direct support for this supposition we investigated whether the addition of [U4/U6.U5] tri-snRNP-specific proteins to Mono-Q-purified 20S U5 and 10S U4/U6 snRNPs would bring about stable 25S [U4/U6.U5] complex formation. In addition, this assay would allow the investigation of a possible role of ATP in the in vitro assembly of the tri-snRNP complex.

Initial attempts to isolate the [U4/U6.U5]-specific proteins by the EDTA shock procedure on DEAE 53 (Walter and Blobel 1983) failed, owing to nonspecific adsorption of these proteins to the cellulose matrix. Therefore, we pursued the following strategy. Isolated [U4/U6.U5] complex was digested extensively with micrococcal nuclease (MN) such that no intact U4, U5, and U6 snRNAs remained (see Fig. 6A, lane 2). This treatment should solubilize at least a certain fraction of the [U4/U6.U5]specific proteins. (The MN-treated [U4/U6.U5] trisnRNP complex henceforth will be referred to as $\mathrm{MN}$ digest.) After inactivation of the MN by EGTA, MonoQ-purified 20S U5 snRNPs and 10S U4/U6 snRNPs /contaminated with U1 snRNPs to varying degrees) were added to the $\mathrm{MN}$ digest and incubated at $37^{\circ} \mathrm{C}$ to allow for assembly of [U4/U6.U5] tri-snRNP complexes.

Initially we assayed the reconstitution of stable [U4/ U6.U5] complexes by determining whether U4/U6 snRNPs coimmunoprecipitate with U5 snRNPs using mAb H386 (Fig. 6A). (The immunoprecipitation assay was reliable as we could demonstrate that on Western blots, none of the five [U4/U6.U5] tri-snRNP-specific proteins reacts with $\mathrm{H} 386$; data not shown.) Figure 6A, lane 3 , shows that in the absence of the $\mathrm{MN}$ digest from the reconstitution mixtures, $\mathrm{mAb} \mathrm{H} 386$ precipitates predominantly U5 and U1 snRNPs. Only trace quantities of 


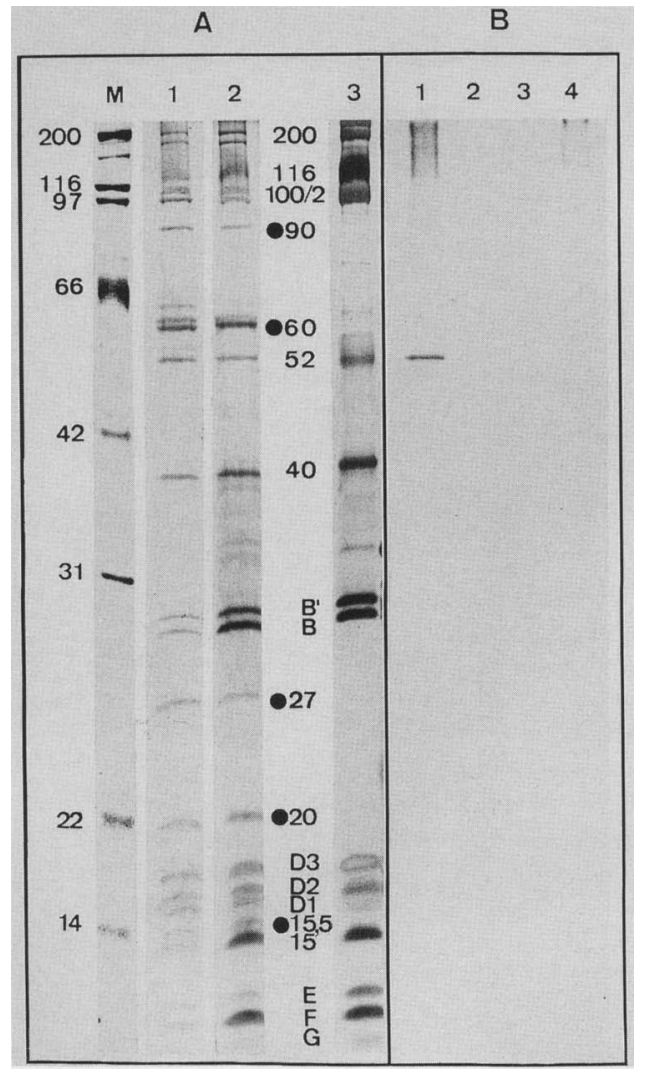

Figure 5. Protein composition and kinase activity of the [U4/ U6.U5] complex. (A) Protein composition of the purified [U4/ U6.U5] tri-snRNP complex. The proteins were separated by $12 \%$ SDS-polyacrylamide gel electrophoresis with high TEMED concentrations to analyze the different $\mathrm{D}$ proteins and visualized by Coomassie blue or silver staining. (Lane $M$ ) Protein markers in $\mathrm{kD}$; (lane 1) The protein composition of the [U4/U6.U5] complex (10 $\mu \mathrm{g})$ after immunoaffinity chromatography and gradient centrifugation (Coomassie blue staining); (lane 2) same as lane 1, but proteins were silver stained; (lane 3) for comparison, $30 \mu \mathrm{g}$ of protein isolated from 20S U5 snRNPs was separated on the same gel and silver-stained. U5 proteins were intentionally overloaded to demonstrate the absence of the five novel proteins found in the [U4/U6.U5] complex. The U5 preparation was slightly contaminated by U1 snRNPs, as evidenced by the presence of residual amounts of U1-A and U1-70K. In lane 2, bands corresponding to proteins not present in the $20 S$ U5 snRNPs are indicated by solid circles. $(B)$ Detection of kinase activity in [U4/U6.U5]. As described in Materials and methods, $10 \mu \mathrm{g}$ of the purified [U4/U6.U5] complex and purified $20 \mathrm{~S}$ U5 snRNPs were incubated together with $\left[\gamma^{-32} \mathrm{P}\right]$ ATP or $\left[\gamma^{-32} \mathrm{P}\right] \mathrm{GTP}$ before electrophoresis on a protein gel under the same conditions as described above. The autoradiograph obtained is shown and can be compared directly with the corresponding protein pattern in $A$. (Lane 1) [U4/U6.U5] incubated with ATP; (lane 2) [U4/U6.U5] incubated with GTP; (lane 3) U5 incubated with GTP; (lane 4) U5 incubated with ATP.

U4/U6 snRNPs are observed in the immune precipitate, probably due to nonspecific adsorption of U4/U6 snRNPs to the Sepharose matrix (Fig. 6A, lane 3). However, upon incubation of the U4/U6 and U5 snRNPs with increasing amounts of the $\mathrm{MN}$ digest, increasing amounts of U4 RNA were observed in the H386 immune precipitate (Fig. 6A, lanes 4 and 5). A slight increase in U6 RNA in the H386 immune precipitate was also observed in the presence of the MN digest (Fig. 6A). As discussed in Figure 3, the under-representation of U6 RNA in the immune precipitate is an apparent one, owing to the inefficient labeling of this RNA with pCp. Therefore, the results indicate that some or all of the free [U4/U6.U5]-specific proteins in the MN digest interact with newly added purified U5 and U4/U6 snRNPs and, thus, bring about [U4/U6.U5] tri-snRNP formation in a concentration-dependent manner.

The above notion was further substantiated when we investigated the reconstitution of $25 \mathrm{~S}$ [U4/U6.U5] complexes by glycerol gradient centrifugation. Figure 6B, panel I, shows the migration of the Mono-Q-purified U4/ U6 and U5 snRNPs in the gradient. Although the $10 \mathrm{~S}$ U4/U6 snRNPs peak in fractions 3 and 4, the 20S U5 snRNPs are found predominately in fractions 6 and 7 (Fig. 6B). After incubation of the purified U4/U6 and U5 snRNPs with the MN digest of isolated [U4/U6.U5] complexes, the sedimentation of the snRNPs was altered. A significant fraction of U4 RNA was shifted to higher S values and was found in fractions 8-10 of the gradient, that is, at 25S. A shift of a fraction of U5 snRNP to the $25 \mathrm{~S}$ region was also clearly observed (cf. lanes 8-10 of panels $I$ and II in Fig. 6B). Identification of U6 RNA in the gradient was obscured by the presence of fragments derived from U1 (at the 10S region) and U5 RNA (at the 20S region) that run at the same position as $\mathrm{U} 6$ in the polyacrylamide gel (Fig. 6B).

When the purified 10S U4/U6 and 20S U5 snRNPs were incubated with a MN digest of isolated 10S U4/U6 and $20 \mathrm{~S}$ U5 snRNPs, instead of the MN digest of [U4/ U6.U5] tri-snRNP complexes, the sedimentation behavior of the 10S U4/U6 and 20S U5 snRNPs remained unchanged and no $25 \mathrm{~S}$ [U4/U6.U5] tri-snRNP particle was brought about under these conditions (Fig. 6C). This excludes the possibility that purified $\mathrm{U} 4 / \mathrm{U} 6$ and $\mathrm{U} 5$ snRNP particles that come off of Mono-Q columns are made competent to associate with each other by the addition of free core or U5-specific proteins. Therefore, these results further support the idea that some or all of the [U4/U6.U5] tri-snRNP-specific proteins are required for stable interaction between purified U4/U6 and U5 snRNPs.

\section{Formation or stability of [U4/U6.U5] complexes is not affected by ATP}

Because the isolated [U4/U6.U5] complex contains an ATPase and kinase activity (Fig. 5B), we were interested in investigating whether ATP affects the associationdissociation equilibrium of the tri-snRNP complex. In Figure 7A we have tested whether ATP enhances the reconstitution of [U4/U6.U5] tri-snRNP complexes from purified U5 and U4/U6 snRNPs and free [U4/U6.U5] trisnRNP-specific proteins (MN digest). No differences could be observed in the coprecipitation of U4/U6 with 


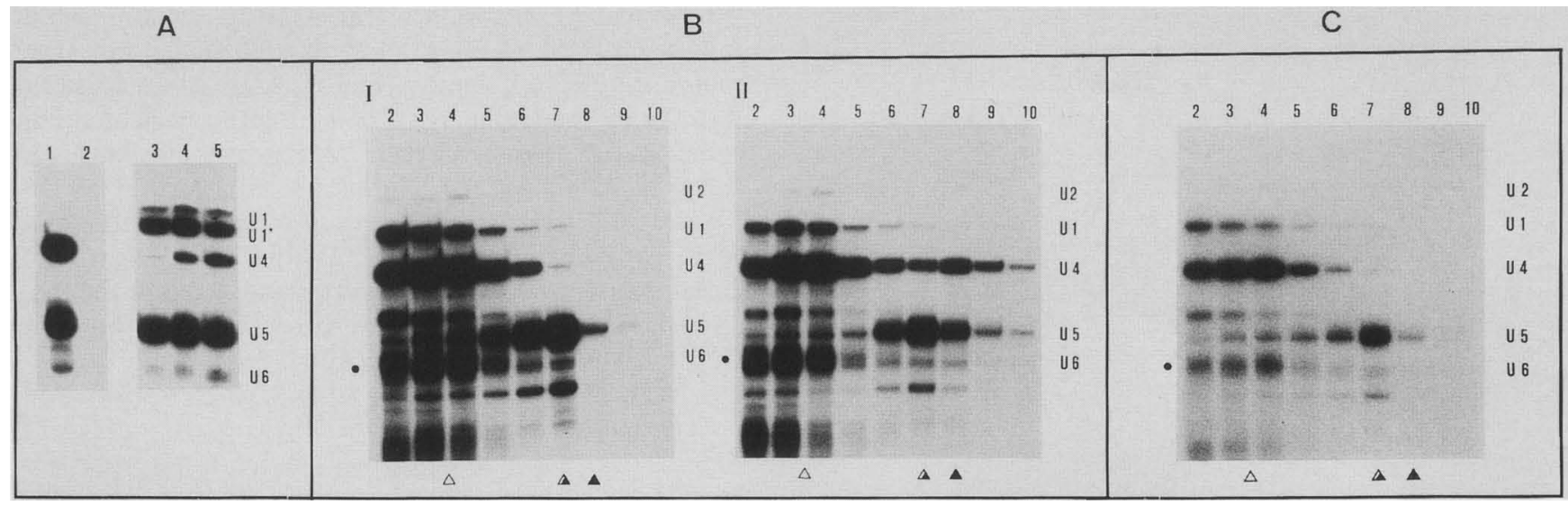

Figure 6. Formation of $25 \mathrm{~S}$ [U4/U6.U5] complexes from purified U5 and U4/U6 monoparticles and free [U4/U6.U5]-specific proteins. (A) Immunoprecipitation analysis. [U4/U6.U5] tri-snRNP complexes purified by mAb H386 affinity chromatography and gradient centrifugation (cf. Fig. 4) were digested extensively with MN (see Materials and methods) so that no intact U4, U5, and U6 snRNAs remained [cf. RNA composition before (lane 1) and after (lane 2) MN digestion]. Varying amounts of the MN digest were incubated, together with $5 \mu \mathrm{g}$ of U4/U6 snRNPs (contaminated with U1 snRNPs) and $5 \mu \mathrm{g}$ of $20 \mathrm{~S}$ U5 snRNPs, both purified by Mono-Q chromatography for $30 \mathrm{~min}$ at $37^{\circ} \mathrm{C}$ (for details, see Materials and methods). Formation of [U4/U6.U5] complexes was then assayed by immunoprecipitation with mAb H386. Immunoprecipitation assays were carried out as described in Materials and methods. An autoradiograph of the gel-fractionated $\left(10 \%\right.$ polyacrylamide, $8 \mathrm{M}$ urea) $\left[{ }^{32}\right] \mathrm{pCp}$-labeled snRNAs from the various immunoprecipitates is shown. (Lanes 1 and 2) The RNA composition of $2 \mu \mathrm{g}$ of purified [U4/U6.U5] complexes before (lane 1) and after (lane 2) treatment with $\mathrm{MN}$; (lane 3) precipitate of mAb H386 with purified U4/U6(U1) and 20S U5 snRNPs (U1* represents a degradation product of U1 RNA lacking the 5'-terminal $\sim 10$ nucleotides); (lanes 4 and 5) precipitate of mAb H386 with purified U4/U6(U1) and U5 snRNPs after incubation with $5 \mu \mathrm{g}$ (lane 4) or $10 \mu \mathrm{g}$ (lane 5) of $\mathrm{MN}$ digest of isolated [U4/U6.U5] complexes. (B) Glycerol gradient centrifugation of reconstituted [U4/U6.U5] complexes. Ten micrograms of U4/U6 (contaminated with Ul snRNPs) and $10 \mu \mathrm{g}$ of $20 \mathrm{~S}$ U5 snRNPs purified by Mono-Q chromatography were incubated together with $75 \mu \mathrm{l}$ of $\mathrm{MN}$-digested [U4/U6.U5] complexes (10 $\mu \mathrm{g})$ and subjected to centrifugation in a 2-ml $10-30 \%$ glycerol gradient as described in Materials and methods. The RNP particles in the various fractions $(200 \mu \mathrm{l})$ were phenolized, and the RNAs were $3^{\prime}$-end-labeled with $\left[{ }^{32}\right] \mathrm{pCp}$ and fractionated in $10 \%$ polyacrylamide gels containing 8 $M$ urea and autoradiographed. (I) Sedimentation of the Mono-Q-purified snRNPs in the absence of free [U4/U6.U5] tri-snRNP-specific proteins. (II) The sedimentation of U4/U6 and U5 snRNPs after incubation with the MN digest of isolated [U4/U6.U5] complexes. Sedimentation is from left to right. Triangles at bottom indicate positions of $10 \mathrm{~S}$ snRNPs $(\triangle)$, 20S U5 snRNPs (U), and 25S [U4/U6.U5] tri-snRNPs $(\Delta)$. ( at left of $A, B$, and $C)$ Positions in the gels where fragments of U1 or U5 snRNAs migrate. (C) Free common snRNP proteins and U5-specific proteins do not promote assembly of [U4/U6.U5] tri-snRNPs. Ten micrograms of U4/U6 [contaminated with U1 snRNPs) and $10 \mu \mathrm{g}$ of $20 \mathrm{~S}$ U5 snRNPs purified by Mono-Q chromatography were incubated together with $80 \mu \mathrm{l}$ of a mixture of MN-digested purified U4/U6 and 20S U5 snRNPs (10 $\mu$ g each) and subjected to centrifugation in a 2-ml 10-30\% glycerol gradient as described in Materials and methods. Sedimentation of snRNPs and analysis of snRNAs were carried out essentially as described for $B$ (for explanation of symbols, see $B$, above).

U5 snRNPs by mAb H386, when reconstitution was carried out either in the presence or absence of ATP (Fig. 7A, lanes 1 and 2). The stability of isolated [U4/U6.U5] complexes was also not significantly affected by the presence of ATP. This is shown in Figure 7B by glycerol gradient centrifugation of purified tri-snRNP complexes sedimented in the absence (panel I) or presence (panel II) of ATP. In both instances, the majority of U4/U6 and U5 sediments at the $25 \mathrm{~S}$ region. The same results were obtained when the effect of ATP on the stability of [U4/ U6.U5] complexes was tested by immunoprecipitation with mAb H386 (not shown).

\section{Discussion}

In this article we describe the isolation of stable trisnRNP [U4/U6.U5] complexes from HeLa cells under native conditions. This was accomplished with a monoclo- nal antibody, H386, that reacts with both the U1-specific $70 \mathrm{~K}$ and the U5-specific $100-\mathrm{kD}$ protein (Fig. 2). Immunoprecipitation clearly demonstrated that the epitope on the $100-\mathrm{kD}$ protein that is recognized by $\mathrm{H} 386$ is accessible for antibody binding not only in free U5 but also when U5 is part of the tri-snRNP complex, [U4/U6.U5] (Fig. 3). The fact that U5 and U4/U6 are coprecipitated by $\mathrm{H} 386$ demonstrates that $\mathrm{U} 5$ is stably associated with $\mathrm{U} 4$ / U6 in HeLa nuclear extract.

The intensities of the $100-\mathrm{kD}$ protein observed by immunoblotting and ELISA assays employing $\mathrm{H} 386$ were comparable with those of the $70 \mathrm{~K}$ protein, which suggests that the epitopes of these antigens have largely similar structures. It was found that a synthetic polypeptide, constructed on the basis of other epitope mapping studies with $70 \mathrm{~K}$ cDNA subclones and containing the presumed linear epitope for $\mathrm{H} 386$, could be used for desorption of antibody-bound [U4/U6.U5] complexes from an $\mathrm{H} 386$ affinity column. This allowed the isolation of 
[U4/U6.U5] under native conditions (Fig. 4A). The U1 snRNPs that were also eluted from the $\mathrm{H} 386$ affinity column by the application of the synthetic peptide interact with $\mathrm{H} 386$ independent of the [U4/U6.U5] complex. This was shown by a control precipitation with H111, which recognizes the U1-70K protein alone and the successful separation of U1 from [U4/U6.U5] by subsequent glycerol density gradient centrifugation (Fig. 4B).

The procedure of isolation by immunoaffinity chromatography and subsequent separation from U1 by glycerol density gradient centrifugation not only shows that U4/ U6 and U5 are desorbed from the column as a tri-snRNP complex [U4/U6.U5] but also that this complex is remarkably stable, with the sedimentation coefficient remaining at $25 \mathrm{~S}$ throughout the purification procedure. This suggests that the tri-snRNP population is homogeneous, a supposition recently confirmed by electron microscopy data (B. Kastner, unpubl.). Another indication of the stability of the [U4/U6.U5] complex is that an identical protein composition is reproducibly observed from one preparation to the next. We observe three groups of proteins within the [U4/U6.U5] tri-snRNP:

1. Common proteins, which associate with U5 and U4 and are also present in U1 and U2 snRNPs.

2. U5-specific proteins, as found in $20 \mathrm{~S}$ U5 snRNPs. All
U5-specific proteins in the tri-snRNP complex appear to be retained during the association with U4/U6. An exception could be the $52-\mathrm{kD}$-protein, which was found in varying quantities from one preparation to the next. Interestingly, this protein was also phosphorylated in the [U4/U6.U5] complex.

3 . Previously unidentified proteins with respective molecular masses of $90,60,27,20$, and $15.5 \mathrm{kD}$. They are present in substantial quantities and are found exclusively in the multiple snRNP complex (i.e., not in $20 \mathrm{~S}$ U5 or in 10S U4/U6 snRNPs).

These proteins can be reproducibly detected both in the coeluate containing $U 1$ and in the U1-free $25 S$ peak after centrifugation (Fig. 5). We may therefore reasonably assume that these proteins are specifically associated with the [U4/U6.U5] complex. Because of the stringent isolation conditions, every protein that comigrates with the U4, U5, and U6 snRNAs may be regarded as being a genuine component of the tri-snRNP complex. In addition, these proteins are not present in $20 \mathrm{~S}$ U5 particles isolated from nuclear extracts, indicating that they are not merely nonspecifically associated with U5 snRNA.

This group of proteins found only in purified $25 \mathrm{~S}$ trisnRNP particles appears to be important for the formation of the [U4/U6.U5] complex. This notion is sup-

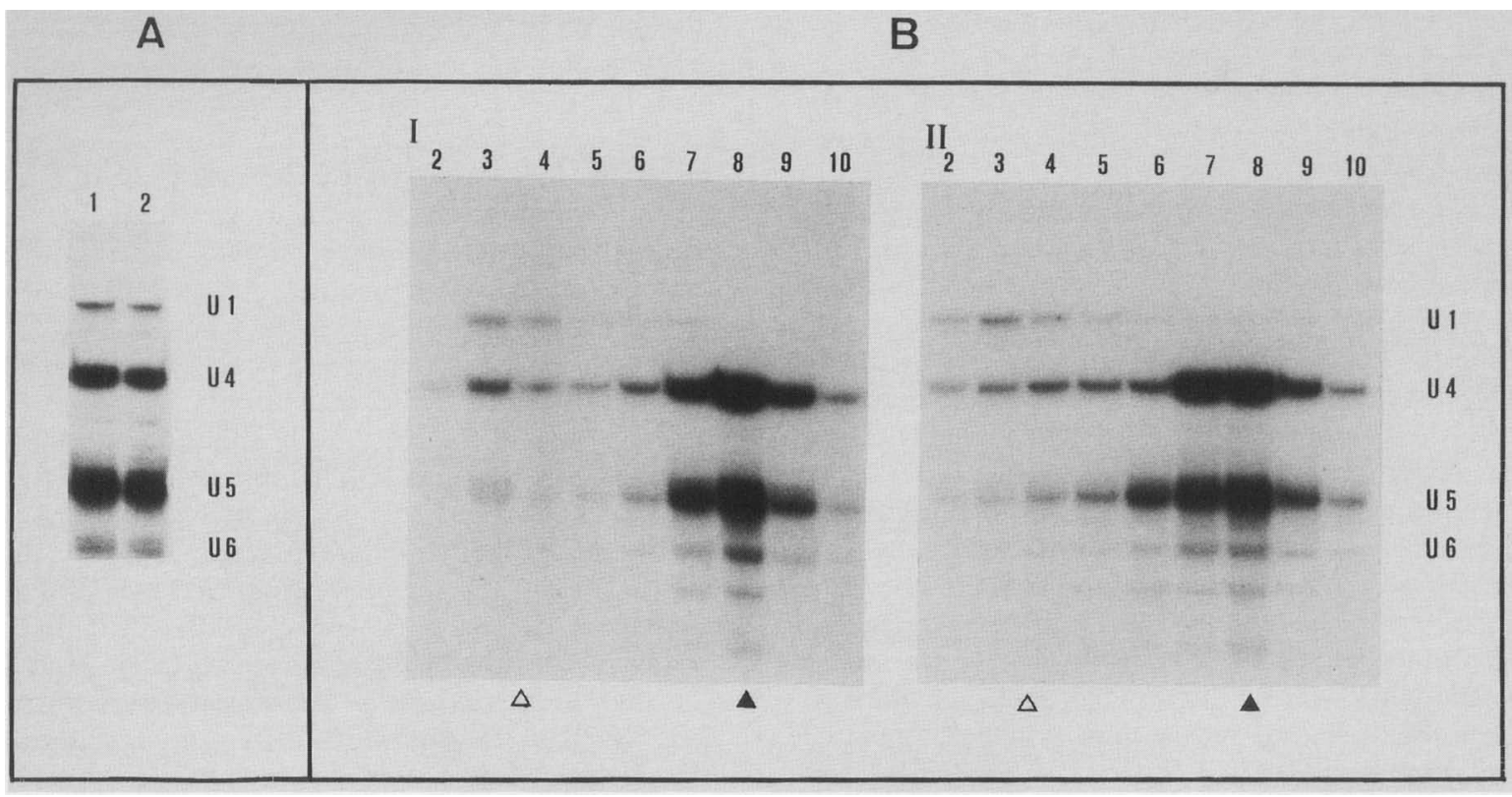

Figure 7. Effect of ATP on the formation or stability of [U4/U6.U5] complexes. (A) Immunoprecipitation of [U4/U6.U5] complexes with $\mathrm{H} 386$ reconstituted from purified U4/U6 and U5 snRNPs and free [U4/U6.U5]-specific proteins in the absence (lane 1) and presence (lane 2) of ATP (1.5 mM). Reconstitution of [U4/U6.U5] tri-snRNP complexes and immunoprecipitation with mAb H386 were carried out essentially as described for Fig. 6A, lane 5. An autoradiograph of the gel-fractionated $\left[{ }^{32}\right]$ pCp-labeled snRNAs from the immunoprecipitates is shown. $(B)$ Glycerol gradient centrifugation of purified [U4/U6.U5] tri-snRNP complexes in the absence $(I)$ or presence (II) of ATP. Twenty micrograms of purified [U4/U6.U5] complexes (peptide eluate of an H386 column, Fig. 4A) was incubated for $1 \mathrm{hr}$ at $37^{\circ} \mathrm{C}$ in the absence $(I)$ or presence of $1.5 \mathrm{mMATP}(I I)$ and subjected to centrifugation in $2 \mathrm{ml}$ of $10-30 \%$ glycerol gradients. The gradient in $I I$ also contained $1.5 \mathrm{mM}$ ATP. Fractionation of the gradients and analysis of the RNA composition of the various gradient fractions were carried out as described in Figure 6B. Triangles at bottom of $A$ and $B$ indicate the position of $10 \mathrm{~S}$ snRNPs $(\triangle)$ and $25 \mathrm{~S}$ [U4/U6.U5] tri-snRNP complexes (A). 
ported by at least two kinds of experimental evidence. (1) snRNPs purified by anti- $m_{3} G$ affinity chromatography under high salt conditions do not reassociate to form a stable [U4/U6.U5] complex under moderate ionic conditions comparable with those found in splicing extracts (Fig. 1). Apparently, these proteins dissociate during the nuclear extract preparation and are lost during the subsequent purification step. (2) The importance of the trisnRNP-specific proteins for the association between U4/ U6 and U5 snRNPs was demonstrated more directly by an in vitro reconstitution assay: When isolated $20 \mathrm{~S}$ U5 and $10 S$ U4/U6 snRNPs were incubated with a MN digest of [U4/U6.U5] complexes (i.e., with solubilized trisnRNP-specific proteins) and subjected to immunoprecipitation with mAb $\mathrm{H} 386$, significant coprecipitation of U4 RNA with U5 RNP was observed (Fig. 6A). In addition, when the reconstitution mixture was subjected to sedimentation in glycerol gradients, U4 and U5 RNA comigrated at $25 \mathrm{~S}$, that is, to the position where native [U4/U6.U5] complexes usually migrate. This was not observed in the absence of free tri-snRNP-specific proteins (Fig. 6B,C). Although U6 was apparently under-represented, both in the $\mathrm{H} 386$ immunoprecipitate and in the $25 \mathrm{~S}$ gradient fractions (Fig. 6B), this can be explained by the inefficient labeling of U6 RNA with pCp. Because there is no evidence that the free tri-snRNP-specific proteins would dissociate U4/U6 snRNPs, we may therefore assume that these proteins are required for stable [U4/ U6.U5] tri-snRNP complex formation by interaction with purified $20 S$ U5 and 10S U4/U6 snRNPs.

The question as to whether all of the five proteins, observed exclusively in the isolated 25S [U4/U6.U5] trisnRNP, are involved in assembly of the tri-snRNP complex cannot be answered at present. It is possible that in nuclear extracts, at low salt concentrations, some of these proteins may interact directly with U4/U6 snRNPs independent of U5 snRNP (and may thus be considered as $\mathrm{U} 4 / \mathrm{U} 6$ specific) and that, in the extreme case, only one of the five novel proteins is promoting [U4/U6.U5] tri-snRNP assembly. These questions will be answered once individually purified proteins are available for in vitro tri-snRNP reconstitution experiments.

In Saccharomyces cerevisiae, the PRP4 protein has been shown to be essential for the formation of the [U4/ U6.U5] complex. The interaction between the two snRNPs, U4/U6 and U5, probably involves the conserved 5' stem-loop of the U4 snRNA, the region where PRP4 is thought to bind (Bordonné et al. 1990; Xu et al. 1990). Another protein, PRP3, may also be associated with the yeast tri-snRNP, as a defective PRP4 gene can be complemented by extra copies of the PRP3 gene (Last et al. 1987). It is therefore very probable that the proteins present in the isolated human [U4/U6.U5] complex and responsible for the association of these snRNPs with one another include mammalian counterparts to PRP3 and PRP4. Once antibodies are available for the various U4/ U5/U6 proteins of $\mathrm{HeLa}$, a more detailed investigation of RNA-protein and protein-protein interactions in the 25S tri-snRNP complex will be possible.

It has long been known that ATP is needed both for the incorporation of $\mathrm{U} 2$ and $\mathrm{U} 4 / \mathrm{U} 5 / \mathrm{U} 6$ into the spliceosome and for the splicing process itself. For U2, the process of branchpoint recognition appears to be coupled to the binding and/or the hydrolysis of ATP (Burgess et al. 1990). With regard to the ATP dependence of the association or dissociation of [U4/U6.U5], available data in HeLa and yeast are contradictory /Cheng and Abelson 1987; Konarska and Sharp 1987; Lossky et al. 1987; Black and Pinto 1989; Bordonné et al. 1990). We have therefore investigated the influence of ATP on the association-dissociation equilibrium between U4/U6 and U5 snRNPs in the absence of nuclear extract and have observed no measurable ATP effects. 25S [U4/U6.U5] complexes were reconstituted from isolated $20 \mathrm{~S}$ U5 and $10 \mathrm{~S}$ U4/U6 in the presence of free tri-snRNP-specific proteins with the same efficiency in both the presence and absence of ATP (Fig. 7A). Furthermore, no significant dissociation of [U4/U6.U5] tri-snRNP complexes, purified from splicing extracts, could be detected by incubation with ATP (Fig. 7B).

Recently, Black and Pinto (1989) showed that in HeLa cell nuclear extracts the appearance of [U4/U6.U5] trisnRNP complexes was dependent on the presence of ATP: Depletion of ATP from nuclear extracts eliminated the complex. De novo formation of [U4/U6.U5] complexes, on the other hand, was only observed in the presence of ATP (Black and Pinto 1989). Thus, it appears that additional factors absent from our purified snRNPs may act on the [U4/U6.U5] tri-snRNP complex in nuclear extracts. It could be envisaged, for example, that in nuclear extracts one or more of the tri-snRNP-specific proteins must be activated in an ATP-dependent manner, for example, by post-translational modifications to promote stable [U4/U6.U5] complex formation. In our reconstitution system we use proteins from isolated [U4/U6.U5] complexes that are therefore already active and are able to promote stable association between U4/U6 and U5 snRNPs in an ATP-independent way.

An interesting observation arising from this work is the detection of ATP kinase activity in the [U4/U6.U5] complex and the selective phosphorylation in vitro of one of the proteins in this complex. This protein has a molecular mass of $52 \mathrm{kD}$, and evidence from SDS-polyacrylamide gel electrophoresis (Fig. 5) strongly suggests that it is the $52-\mathrm{kD}$ U5-specific protein. The identity of the kinase activity is not yet clear. Our finding that the $52-\mathrm{kD}$ protein is not phosphorylated in isolated $20 \mathrm{~S}$ U5 particles suggests that the kinase activity is intrinsic to the [U4/U6.U5] complex. The important question whether one of the five tri-snRNP-specific proteins is the kinase or whether this activity is due to an additional not yet identified minor protein associated with isolated tri-snRNP complexes can only be answered once the individual polypeptides are purified in native form.

The functional significance of the ATPase and kinase activities is, at present, unclear. However, the data discussed above would make a role of this ATP-dependent phosphorylation in the dissociation-association equilibrium of U4/U6 and U5 snRNPs rather unlikely. In view of the evidence that a conformational rearrangement 
within the U4/U6 interaction domain occurs either before or concomitant with the first step of the splicing reaction, it is tempting to speculate that ATP could play a part in the conversion of the spliceosome-integrated [U4/U6.U5] complex to its active form.

\section{Materials and methods}

\section{Preparation of HeLa nuclear extract}

HeLa cells (S3) were grown in suspension culture as described previously (Bringmann et al. 1983). Nuclear extracts (splicing extracts) were prepared by the method of Dignam et al. (1983) with slight modifications (see below).

\section{Anti-m ${ }_{3} G$ immunoaffinity chromatography of snRNPs}

The affinity purification of U1-U6 snRNPs was performed using $\mathrm{mAb} \mathrm{H}-20$ bound covalently to $\mathrm{CNBr}$-activated Sepharose 4B (Pharmacia) as described previously (Bochnig et al. 1987). Nuclear extracts were prepared from $5 \times 10^{9}$ up to $1 \times 10^{10}$ cells in buffer C-5, containing $20 \mathrm{mM} \mathrm{HEPES} / \mathrm{KOH}(\mathrm{pH} 7.9), 420$ $\mathrm{mM} \mathrm{NaCl}, 1.5 \mathrm{mM} \mathrm{MgCl}_{2}, 0.2 \mathrm{~mm}$ EDTA-NaOH $(\mathrm{pH} 8), 0.5 \mathrm{~mm}$ DTE, $0.5 \mathrm{~mm}$ PMSF, $4 \mu \mathrm{g} / \mathrm{ml}$ of leupeptin, and $5 \%$ glycerol, and were subsequently passed over an anti- $m_{3} G$ affinity column (bed volume $5 \mathrm{ml}$ ) that had been equilibrated in the same buffer. Washing and desorption of the antibody-bound snRNPs by elution with $\mathrm{m}^{7} \mathrm{G}$ was carried out as described previously (Bringmann et al. 1986), using buffer C-5 for all steps.

\section{FPLC of U1-U6 SnRNPS}

Purification of U1, U2, 10 S or 20 S U5, and U4/6 snRNPs was accomplished by Mono-Q chromatography of U1-U6 snRNPs isolated by anti- $\mathrm{m}_{3} \mathrm{G}$ affinity chromatography. This procedure is described by Bach et al. (1989).

\section{Western blotting}

Total protein of U1-U6 snRNPs $(100-300 \mu \mathrm{g})$, purified as described above, was loaded at $10-30 \mu \mathrm{g} / \mathrm{cm}$ onto $5-20 \%$ SDSpolyacrylamide gradient gels. After gel electrophoresis, the proteins were transferred electrophoretically onto nitrocellulose (Towbin et al. 1979). The transfer was carried out in SLAB-4 buffer [ $20 \mathrm{~mm}$ Tris- $\mathrm{HCl}$ (pH 8.3), $150 \mathrm{~mm}$ glycine, $2 \%$ SDS] in a semidry blotting apparatus. Immunodetection with monoclonal antibodies was carried out as described by Reuter and Lührmann (1986). Antigen-bound antibodies were visualized with a second antibody conjugated with alkaline phosphatase (Sigma) that catalyzes the color reaction of 5-bromo-4-chloro-indolyl phosphate and nitrotetrazolium blue.

\section{ELISA assay}

SnRNP proteins were separated on SDS-polyacrylamide gels [ $12 \%$ for low-molecular-mass proteins, $5-8 \%$ for high-molecular-mass proteins $(>70 \mathrm{kD})]$ and isolated from the gels by electroelution as described previously (Reuter et al. 1987). Individual proteins $(5 \mathrm{ng} /$ well) were allowed to bind to polystyrene microtiter plates (Greiner) by drying the plates for $1 \mathrm{hr}$ at $37^{\circ} \mathrm{C}$ in Diabuffer [0.01 $\mathrm{M} \mathrm{NH}_{4} \mathrm{HCO}_{3}, 0.02 \%$ SDS]. A $1: 400$ dilution of the $\mathrm{H} 386$ hybridoma culture supernatant in $80 \mu \mathrm{l}$ of PBS containing $1 \%$ BSA and $0.1 \%$ Tween 20 was added, and the mixture was incubated for $16 \mathrm{hr}$ at $4^{\circ} \mathrm{C}$. Blocking of nonspecific binding sites on the polystyrene surface, washing procedures, and detection of antigen-bound antibodies were carried out es- sentially as described by Rauh et al. (1988). Alkaline phosphatase conjugate was purchased either from Dynatec or from Sigma and was used in a $1: 1000$ dilution. The color reaction of $p$-nitrophenyl phosphate was developed for $15 \mathrm{~min}$ at room temperature. The absorbance at $405 \mathrm{~nm}$ was measured by an automated ELISA reader (Dynatech).

\section{Glycerol gradient sedimentation studies}

Preparative gradient centrifugation Nuclear extracts or anti$\mathrm{m}_{3} \mathrm{G}$ column snRNP eluates (snRNPs U1-U6) were dialyzed for $4 \mathrm{hr}$ against 30 volumes of buffer $\mathrm{G}$ [20 mM HEPES (pH 7.9), 150 $\mathrm{mm} \mathrm{KCl}, 1.5 \mathrm{~mm} \mathrm{MgCl}_{2}, 0.2 \mathrm{~mm}$ EDTA, $0.5 \mathrm{~mm}$ DTE, $0.5 \mathrm{~mm}$ PMSF, $4 \mu \mathrm{g} / \mathrm{ml}$ of leupeptin, $5 \%$ glycerol]. Nuclear extracts prepared under these conditions were active in splicing at $40 \%$ dilution per assay (Winkelmann et al. 1989). Nuclear extract or affinity column eluate $(\leqslant 2.5 \mathrm{ml}$ ) (containing $\leqslant 800 \mu \mathrm{g}$ of snRNPs) was layered onto a linear, $11-\mathrm{ml}, 10-30 \%$ (vol/vol) glycerol gradient prepared with buffer $\mathrm{G}$. The gradients were centrifuged in a Beckman SW 40 Ti rotor at $29,000 \mathrm{rpm}$ for 18 hr. Twenty-six 500- $\mu$ l fractions were harvested from top to bottom and frozen immediately in liquid nitrogen. The protein and RNA content of the fractions was assayed by phenol extraction and electrophoresis of the protein and RNA products, as described previously (Bringmann et al. 1983). When necessary, the three different D proteins were visualized by SDS-polyacrylamide gel electrophoresis using $80 \mu \mathrm{l}$ of ammonium persulfate and $80 \mu \mathrm{l}$ of $N, N, N^{\prime}, N^{\prime}$-tetramethyl-ethylenediamine (TEMED)/20 ml of gel solution as described by Lehmeier et al. (1990).

Analytical gradient centrifugation For the analysis of reconstitution experiments or the influence of ATP on the stability of isolated [U4/U6.U5] tri-snRNPs, $\leqslant 200-\mu 1$ reaction volume containing $\sim 10 \mu \mathrm{g}$ of snRNPs was loaded on a $2-\mathrm{ml} 10-30 \%$ (vol/ vol) glycerol gradient prepared with buffer G. Centrifugation was carried out for $2.5 \mathrm{hr}$ at $55,000 \mathrm{rpm}$ in a Beckman TLS-55 rotor (TL-100 tabletop centrifuge). RNA was extracted from $200-\mu l$ fractions and 3 '-end-labeled with $\left[{ }^{32} \mathrm{P} \mid \mathrm{pCp}\right.$ and electrophoretically analyzed (see also below).

\section{Immunoprecipitation}

Protein A-Sepharose (Pharmacia) was preswollen in PBS buffer [130 mM NaCl, $20 \mathrm{~mm} \mathrm{NaPO}$ (pH 8)]. Twenty-microliter aliquots of a $50 \%$ suspension of beads were mixed with $20 \mu \mathrm{g}$ of purified antibody or $200 \mu \mathrm{l}$ of hybridoma supernatant in a total volume (made up with PBS) of $500 \mu l$. The mixture was incubated overnight at $4^{\circ} \mathrm{C}$ with continual longitudinal rotation of the vessel. If IgM hybridoma supernatant was used, an antiantibody $(20 \mu \mathrm{g}$ of goat anti-mouse IgM, purchased from Sigma) was bound to the protein A-Sepharose before incubation with the supernatant. After the beads had been washed five times with $500 \mu$ l of buffer G, the antigen was added (either $100 \mu$ l of a gradient fraction or 2-5 $\mu$ g of Mono-Q-purified snRNPs in buffer $G)$. The reaction was carried out in $500 \mu$ l of buffer $G$ for at least $4 \mathrm{hr}$ at $4^{\circ} \mathrm{C}$. The protein A-Sepharose was then washed five times with buffer $G$ and transferred to a new reaction tube. After one additional wash, the bound RNA was extracted with phenol and chloroform, precipitated with ethanol, and 3'end-labeled with $\left[{ }^{32} \mathrm{P}\right] \mathrm{pCp}$ (Amersham) by the method of England and Uhlenbeck (1978). Electrophoretic analysis of labeled RNA was carried out with $10 \%$ polyacrylamide gels containing $8 \mathrm{M}$ urea. 
Immunoaffinity chromatography with the anti-70K/100-kD $m A b H 386$

Preparation of the affinity column Goat anti-mouse IgM antibody $(2 \mathrm{mg}$ ) (Sigma) was coupled to $2 \mathrm{ml}$ of protein A-Sepharose $(50 \% \mathrm{vol} / \mathrm{vol}$ beads $)$ as described in the preceding paragraph. After washing with PBS, H386 from 30-ml hybridoma supernatant was coupled to the column. The antibodies were covalently cross-linked to one another and to the protein A-Sepharose with dimethylpimelimidate (Pierce) as described by Harlowe and Lane (1988).

The efficiency of cross-linking was monitored by heating an aliquot of the column material in Laemmli buffer $[60 \mathrm{~mm}$ Tris$\mathrm{HCl}$ [pH 6.8), $100 \mathrm{~mm}$ DTE, $2 \%$ SDS, $10 \%$ glycerol] at $85^{\circ} \mathrm{C}$ for $10 \mathrm{~min}$ and subjecting it to gel electrophoresis on a $12 \%$ SDSpolyacrylamide gel.

Chromatography After equilibration of the Sepharose material with buffer $G, \leqslant 7 \mathrm{ml}$ of collected gradient fractions was applied to the column and incubated in batch form for at least $2 \mathrm{hr}$ at $4^{\circ} \mathrm{C}$ with longitudinal rotation. The flowthrough was collected separately, and the column was washed with 10 volumes of buffer G. Bound snRNPs were eluted with 4 volumes of buffer G containing $50 \mu \mathrm{g}(0.01 \mathrm{~mm})$ of a competing peptide, a 32-mer with the sequence DRDRERRRSHRSERERRRDRRDRDRDRDEHKR, which had been synthesized on an Applied Biosystems 430A peptide synthesizer. The peptide was used directly after removal of contaminating salts by a G-25 Sephadex column. The affinity column was carefully regenerated by washing first with $10 \mathrm{~mm} \mathrm{NaPO}$ buffer $(\mathrm{pH} 7.2)$ and subsequently removing the peptide with a buffer containing $3.5 \mathrm{M}$ $\mathrm{MgCl}_{2}$ and $10 \mathrm{~mm} \mathrm{Na} / \mathrm{PO}_{4}(\mathrm{pH}$ 7.2). After repeated washing with 20 volumes of buffer $\mathrm{G}$ containing $0.02 \%$ azide, the column could be reused.

\section{Detection of kinase activity}

[U4/U6.U5] tri-snRNP complexes, purified by immunoaffinity chromatography with mAb H386 as described above, were subjected to centrifugation in a preparative gradient (see above) to remove contaminating Ul snRNP particles (see Results). To $1-\mathrm{ml}$ glycerol gradient fractions containing $10 \mu \mathrm{g}$ of pure $25 \mathrm{~S}$ [U4/U6.U5] complexes, either $100 \mu \mathrm{Ci}$ of $\left[\gamma^{-32} \mathrm{P}\right]$ ATP or $100 \mu \mathrm{Ci}$ of $\left[\gamma^{-32} \mathrm{P}\right]$ GTP (both from Amersham; sp. act. $\left.>5000 \mathrm{Ci} / \mathrm{mmole}\right)$ was added. After $1 \mathrm{hr}$ incubation at $37^{\circ} \mathrm{C}$, proteins were extracted, fractionated by $12 \%$ SDS-polyacrylamide gel electrophoresis, stained with silver or Coomassie blue, and autoradiographed. In a parallel experiment, $20 \mu \mathrm{g}$ of purified $20 \mathrm{~S}$ U5 snRNPs were subjected to the same conditions as described for the [U4/U6.U5] complex.

\section{Reconstitution assay}

Forty micrograms of purified [U4/U6.U5] complex (see above) was treated with $0.35 \mathrm{U} / \mu \mathrm{l}$ of $\mathrm{MN}$ in the presence of $1.7 \mathrm{~mm}$ $\mathrm{CaCl}_{2}$ and $2.5 \mathrm{mM} \mathrm{MgCl}_{2}$ for $10 \mathrm{~min}$ at $30^{\circ} \mathrm{C}$ in a $300-\mu l$ reaction volume. EGTA was added to a concentration of $20 \mathrm{mM}(\mathrm{pH} 8)$ to stop the reaction. Ten micrograms of Mono-Q-purified U4/U6 snRNPs /which contained varying quantities of U1 and U2 snRNPs, depending on the batch used) and $10 \mu \mathrm{g}$ of Mono-Qpurified U5 snRNPs were then added to the indicated amount of $\mathrm{MN}$ digest and the volume was increased to $200 \mu \mathrm{l}$ with buffer G. After incubation for $30 \mathrm{~min}$ at $37^{\circ} \mathrm{C}$ the reaction mixture was loaded either on an analytical gradient or directly used for an immune precipitation assay with $\mathrm{H} 386$ (see above). In the control assays, identical concentrations of U4/U6 and U5 snRNPs were used and buffer $\mathrm{G}$ was added to the reaction instead of $\mathrm{MN}$ digest.

\section{Acknowledgments}

We are grateful to Hans Will, Hans Netter, and Hans Guldner for communicating their results on the epitope of the U1-70K protein before publication. We are indebted to Cindy L. Will and Vicki Sumpter for many helpful comments and discussions during the preparation of the manuscript. We thank Irene Öchsner-Welpelo for excellent technical assistance and Verena Buckow for help in the preparation of the manuscript. Thanks also go to other members of our laboratory for many discussions throughout the work. This work was supported by grants from the Deutsche Forschungsgemeinschaft and the Fonds der Chemischen Industrie.

\section{References}

Anderson, G.J., M. Bach, R. Lührmann, and J.D. Beggs. 1989. Conservation between yeast and man of a protein associated with U5 small nuclear ribonucleoprotein. Nature 342: 819821.

Bach, M., G. Winkelmann, and R. Lührmann. 1989. 20S small nuclear ribonucleoprotein U5 shows a surprisingly complex protein composition. Proc. Natl. Acad. Sci. 86: 6038-6042.

Bach, M., P. Bringmann, and R. Lührmann. 1990. Purification of small nuclear ribonucleoprotein particles with antibodies against modified nucleotides of small nuclear RNAs. Methods Enzymol. 181: 232-257.

Banroques, J. and J.N. Abelson. 1989. PRP4: A protein of the yeast U4/U6 small nuclear ribonucleoprotein particle. Mol. Cell. Biol. 9: 3710-3719.

Billings, P.B., J.R. Barton, and S.O. Hoch. 1985. A murine monoclonal antibody recognizes the 13,000 molecular weight polypeptide of the Sm small nuclear ribonucleoprotein complex. I. Immunol. 135: 428-432.

Bindereif, A. and M.R. Green. 1987. An ordered pathway of snRNP binding during mammalian pre-mRNA splicing complex assembly. EMBO J. 6: 2415-2424.

Bjorn, S.P., A. Soltyk, J.D. Beggs, and J.D. Friesen. 1989. PRP4 (RNA4) from Saccharomyces cerevisiae: Its gene product is associated with the U4/U6 small nuclear ribonucleoprotein particle. Mol. Cell. Biol. 9: 3698-3709.

Black, D.L. and A.L. Pinto. 1989. U5 small nuclear ribonucleoprotein: RNA structure analysis and ATP-dependent interaction with U4/U6. Mol. Cell. Biol. 9: 3350-3359.

Blencowe, B.J., B.S. Sproat, U. Ryder, S. Barabino, and A.I. Lamond. 1989. Antisense probing of the human U4/U6 snRNP with biotinylated 2'-OMe RNA oligonucleotides. Cell 59: 531-539.

Bochnig, P., R. Reuter, P. Bringmann, and R. Lührmann. 1987. A monoclonal antibody against 2,2,7-trimethylguanosine that reacts with intact $U$ snRNPs as well as with 7-methylguanosine-capped RNAs. Eur, J. Biochem, 168: 461-467.

Bordonné, R., J. Banroques, J. Abelson, and C. Guthrie. 1990. Domains of yeast U4 spliceosomal RNA required for PRP4 protein binding, snRNP-snRNP interactions and pre-mRNA splicing in vivo. Genes \& Dev. 4: 1185-1196.

Bringmann, P. and R. Lührmann. 1986. Purification of the individual snRNPs U1, U2, U5 and U4/U6 from HeLa cells and characterization of their protein constituents. EMBO $I$. 5: 3509-3516.

Bringmann, P., R. Reuter, J. Rinke, B. Appel, R. Bald, and R. Lührmann. 1983a. 5'-Terminal caps of snRNAs are accessi- 
ble for reaction with 2,2,7-trimethylguanosine-specific antibody in intact snRNPs. I. Biol. Chem. 258: 2745-2747.

Bringmann, P., J. Rinke, B. Appel, R. Reuter, and R. Lührmann. 1983b. Purification of snRNPs U1, U2, U4, U5 and U6 with 2,2,7-trimethylguanosine-specific antibody and definition of their constituent proteins reacting with anti-Sm and anti(U1)RNP antisera. EMBO J. 2: 1129-1135.

Bringmann, P., B. Appel, J. Rinke, R. Reuter, H. Theissen, and R. Lührmann. 1984. Evidence for the existence of snRNAs U4 and $\mathrm{U} 6$ in a single ribonucleoprotein complex and for their association by intermolecular base pairing. EMBO $J$. 3: 1357-1363.

Brow, D. and C. Guthrie. 1988. Spliceosomal RNA U6 is remarkably conserved from yeast to mammals. Nature 334: 213-218.

. 1989. RNA processing: Splicing a spliceosomal RNA. Nature 337: 14-15.

Burgess, S., J.R. Couto, and C. Guthrie. 1990. A putative ATP binding protein influences the fidelity of branchpoint recognition in yeast splicing. Cell 60: 705-717.

Chabot, B., D.L. Black, D.M. LeMaster, and J.A. Steitz. 1985. The $3^{\prime}$ splice site of pre-messenger RNA is recognized by a small nuclear ribonucleoprotein. Science 230: 1344-1349.

Cheng, S.-C. and J. Abelson. 1987. Spliceosome assembly in yeast. Genes \& Dev. 1: 1014-1027.

Dignam, J.D., R.M. Lebotiz, and R.G. Roeder. 1983. Accurate transcription initiation by RNA polymerase II in a soluble extract from isolated mammalian nuclei. Nucleic Acids Res. 11: 1475-1489.

England T.E. and O.C. Uhlenbeck. 1978. 3'-Terminal labelling of RNA with T4 RNA ligase. Nature 275: 560-561.

Fabrizio, P. and J. Abelson. 1990. Two domains of yeast U6 small nuclear-RNA required for both steps of nuclear precursor messenger-RNA splicing. Science 250: 404-409.

Garcia-Blanco, M.A., G.J. Anderson, J. Beggs, and P.A. Sharp. 1990. A mammalian protein of $220 \mathrm{kDa}$ binds pre-mRNAs in the spliceosome: A potential homologue of the yeast PRP8 protein. Proc. Natl. Acad. Sci. 87: 3082-3086.

Gerke, V. and J.A. Steitz. 1986. A protein associated with small nuclear ribonucleoprotein particles recognizes the $3^{\prime}$ splice site of premessenger RNA. Cell 47: 973-984.

Green, M.R. 1986. Pre-mRNA splicing. Annu. Rev. Genet. 20: $671-708$.

Guthrie, C. 1989. Catalytic RNA and RNA splicing. Am. Zool. 29: $557-567$.

Guthrie, C. and B. Patterson. 1988. Spliceosomal snRNAs. Annu. Rev. Genet. 22: 387-419.

Harlowe, E. and D. Lane. 1988. Antibodies: A laboratory manual. Cold Spring Habor Laboratory, Cold Spring Habor, New York.

Hashimoto, C. and J.A. Steitz. 1984. U4 and U6 RNAs coexist in a single small nuclear ribonucleoprotein particle. Nucleic Acids Res. 12: 3283-3293.

Heinrichs, V., M. Bach, G. Winkelmann, and R. Lührmann. 1990. U1-specific protein C needed for efficient complex formation of U1 snRNP with a $5^{\prime}$ splice site. Science 247: 6972.

Jackson, S.P., M. Lossky, and J.D. Beggs. 1988. Cloning of the RNA8 gene of Saccharomyces cerevisiae, detection of the RNA8 protein, and demonstration that it is essential for nuclear pre-mRNA splicing. Mol. Cell. Biol. 8: 1067-1075.

Konarska, M.M. and P.A. Sharp. 1987. Interactions between small nuclear ribonucleoprotein particles in formation of spliceosomes. Cell 49: 763-774.

. 1988. Association of U2, U4, U5 and U6 small nuclear ribonucleoproteins in a spliceosome-type complex in ab- sence of precursor RNA. Proc. Natl. Acad. Sci. 85: 54595462.

Krämer, A., W. Keller, B. Appel, and R. Lührmann. 1984. The 5' terminus of the RNA moiety of Ul small nuclear ribonucleoprotein particles is required for the splicing of messenger RNA precursors. Cell 38: 299-307.

Lamond, A.I., M.M. Konarska, P.J. Grabowski, and P.A. Sharp. 1988. Spliceosome assembly involves binding and release of U4 small nuclear ribonucleoprotein. Proc. Natl. Acad. Sci. 85: $411-415$.

Last, R.L., J.R. Maddock, and J.L. Woolford, Jr. 1987. Evidence for related functions of the RNA genes of Saccharomyces cerevisiae. Genetics 117: 619-631.

Lehmeier, T., K. Foulaki, and R. Lührmann. 1990. Evidence for three distinct common $\mathrm{D}$ proteins in the core RNP structure of the major snRNPs U1, U2, U4/6 and U5, which react differentially with anti-Sm autoantibodies. Nucleic Acids Res. 18: 6475-6484.

Lerner, E.A., M.R. Lerner, C.A. Janeway, Jr., and J.A. Steitz. 1981. Monoclonal antibodies to nucleic acid-containing cellular constituents: Probes for molecular biology and autoimmune disease. Proc. Natl. Acad. Sci. 78: 2737-2741.

Lossky, M., G.J. Anderson, S.P. Jackson, and J. Beggs. 1987. Identification of a yeast snRNP protein and-detection of snRNPsnRNP interactions. Cell 51: 1019-1026.

Lührmann, R. 1988. snRNP Proteins. In Structure and function of major and minor small nuclear ribonucleoprotein particles (ed. M.L. Birnstiel), pp. 71-99. Springer-Verlag, Berlin/ Heidelberg/New York.

Lührmann, R., B. Kastner, and M. Bach. 1990. Structure of spliceosomal snRNPs and their role in pre-mRNA splicing. Biochim. Biophys. Acta 1087: 265-292.

Maniatis, T. and R. Reed. 1987. The role of small nuclear ribonucleoprotein particles in pre-mRNA splicing. Nature 325: 673-678.

Mount, S.M., I. Pettersson, M. Hinterberger, A. Karmas, and J.A. Steitz. 1983. The U1 small nuclear RNA-protein complex selectively binds a $5^{\prime}$ splice site in vitro. Cell 33: 509-518.

Netter, H.J., H.H. Guldner, C. Szostecki, and H. Will. 1991. Major autoantigenic sites of the (U1) small nuclear ribonucleoprotein-specific $68-\mathrm{kDa}$ protein. Scand. I. Immunol. 32: (in press).

Padgett, R.A., P.J. Grabowski, M.M. Konarska, S. Seiler, and P.A. Sharp. 1986. Splicing of messenger RNA precursors. Annu. Rev. Biochem. 55: 1119-1150.

Parker, R., P.G. Siliciano, and C. Guthrie. 1987. Recognition of the TACTAAC box during mRNA splicing in yeast involves base pairing to the U2-like snRNP. Cell 49: 229-239.

Patterson, B. and C. Guthrie. 1987. An essential yeast snRNA with a U5-like domain is required for splicing in vivo. Cell 49: 613-624.

Pikielny, C.W., B.C. Rymond, and M. Rosbash. 1986. Electrophoresis of ribonucleoproteins reveals an ordered assembly pathway of yeast splicing complexes. Nature 324: 341-345.

Rauh, A.J.G., H. Hornig, and R. Lührmann. 1988. At least three distinct $\mathrm{B}$ cell epitopes reside in the C-terminal half of $\mathrm{La}$ protein, as determined by a recombinant DNA approach. Eur. I. Immunol. 18: 2049-2057.

Reuter, R. and R. Lührmann. 1986. Immunization of mice with purified U1 small nuclear ribonucleoprotein (RNP) induces a pattern of antibody specificities characteristic of the anti-Sm and anti-RNP autoimmune response of patients with lupus erythematosus, as measured by monoclonal antibodies. Proc. Natl. Acad. Sci. 83: 8689-8693.

Reuter, R. S. Rothe, and R. Lührmann. 1987. Molecular relationships between snRNP polypeptides as determined by 
rabbit antisera and partial protease digestion. Nucleic Acids Res. 15: 4021-4034.

Rinke, J., B. Appel, H. Blöcker, R. Frank, and R. Lührmann. 1984. The $5^{\prime}$-terminal sequence of U1 RNA complementary to the consensus $5^{\prime}$ splice site of hnRNA is single-stranded in intact U1 snRNP particles. Nucleic Acids Res. 12: 41114126.

Rinke, J., B. Appel, M. Digweed, and R. Lührmann. 1985. Localization of a base paired interaction between small nuclear RNAs U4 and U6 in intact U4/U6 ribonucleoprotein particles by psoralen cross-linking. J. Mol. Biol. 185: 721-731.

Ruby, S.W. and J. Abelson. 1988. An early hierachic role of U1 small nuclear ribonucleoprotein in spliceosome assembly. Science 242: 1028-1035.

Ruskin, B., P.D. Zamore, and M.R. Green. 1988. A factor, U2AF, is required for $\mathrm{U} 2$ snRNP binding and splicing complex assembly. Cell 52: 207-219.

Schwedler-Breitenreuter, G., M. Lotti, M. Stöffler-Meilicke, G. Stöffler, D. Strobel, and A. Böck. 1986. The monoclonal antibody $\mathrm{C} 383$ is directed against the ribosomal protein $\mathrm{S} 1$ of $S$. solfataricus. Hoppe-Seyler's Z. Physiol. Chem. 367: 315.

Seraphin, B. and M. Rosbash. 1988. Identification of functional U1 snRNP-pre-mRNA complexes committed to spliceosome assembly and splicing. Cell 59: $349-358$.

Sharp, P.A. 1987. Splicing of messenger RNA precursors. Science 235: 766-771.

Siliciano, P.G. and C. Guthrie. 1988. 5' Splice site selection in yeast: Genetic alterations in base-pairing with $U 1$ reveal additional requirements. Genes \& Dev. 2: 1258-1267.

Steitz, J.A., D.L. Black, V. Gerke, K.A. Parker, A. Krämer, D. Frendewey, and W. Keller. 1988. Functions of the abundant U-snRNPs. In Structure and function of major and minor small nuclear ribonucleoprotein particles (ed. M.L. Birnstiel), pp. 115-154. Springer-Verlag, Berlin/Heidelberg/New York.

Tazi, J., C. Alibert, J. Temsamani, I. Reveillaud, G. Cathala, C. Brunel, and $\mathrm{Ph}$. Jeanteur. 1986. A protein that specifically recognizes the $3^{\prime}$ splice site of mammalian pre-mRNA introns is associated with a small nuclear ribonucleoprotein. Cell 47: 755-766.

Theissen, H., M. Etzerodt, R. Reuter, C. Schneider, F. Lottspeich, P. Argos, R. Lührmann, and L. Philipson. 1986. Cloning of the human cDNA for the U1 RNA associated 70k protein. $E M B O$ /. 5: 3209-3217.

Towbin, H., T. Staehelin, and J. Gordon. 1979. Electrophoretic transfer of proteins from polyacrylamide gels to nitrocellulose sheets: Procedure and some applications. Proc. Natl. Acad. Sci. 76: 5350-4354.

Walter, P. and G. Blobel. 1983. Disassembly and reconstitution of signal recognition particle. Cell 34: 525-533.

Winkelmann, G., M. Bach, and R. Lührmann. 1989. Evidence from complementation assays in vitro that U5 snRNP is required for both steps of mRNA splicing. EMBO /. 8: 31053112.

Wu, J. and I.L. Manley. 1989. Mammalian pre-mRNA branch site selection by U2 snRNP involves base pairing. Genes \& Dev. 3: 1553-1561.

Xu, Y., S. Petersen-Bjorn, and J.D. Friesen. 1990. The PRP4 (RNA4) protein of Saccharomyces cerevisiae is associated with the $5^{\prime}$ portion of the U4 small nuclear RNA. Mol. Cell. Biol. 10: 1217-1225.

Zhuang, Y. and A. Weiner. 1986. A compensatory base change in U1 snRNA suppresses a $5^{\prime}$ splice site mutation. Cell 46: $827-835$.

1989. A compensatory base change in human U2 snRNA can suppress a branch site mutation. Genes \& Dev.
3: $1545-1552$.

Zucker-Aprison, E., J.D. Thomas, and T. Blumenthal. 1988. C. elegans snRNAs: A model for U4/U6 base pairing. Nucleic Acids Res. 16: 7188-7198. 


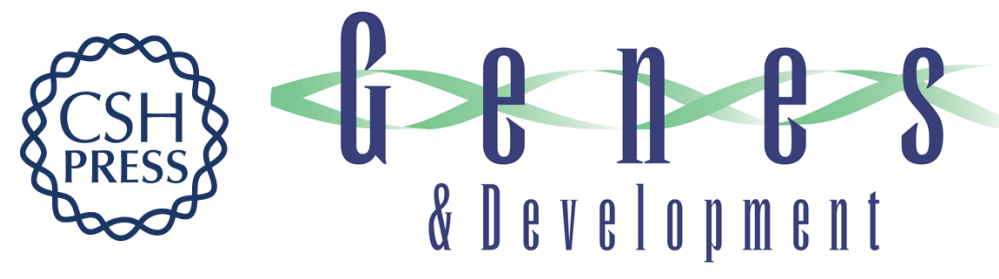

\section{Immunoaffinity purification of a [U4/U6.U5] tri-snRNP from human cells.}

S E Behrens and R Lührmann

Genes Dev. 1991, 5:

Access the most recent version at doi:10.1101/gad.5.8.1439

References This article cites 67 articles, 25 of which can be accessed free at: http://genesdev.cshlp.org/content/5/8/1439.full.html\#ref-list-1

License

Email Alerting

Service

Receive free email alerts when new articles cite this article - sign up in the box at the top right corner of the article or click here.

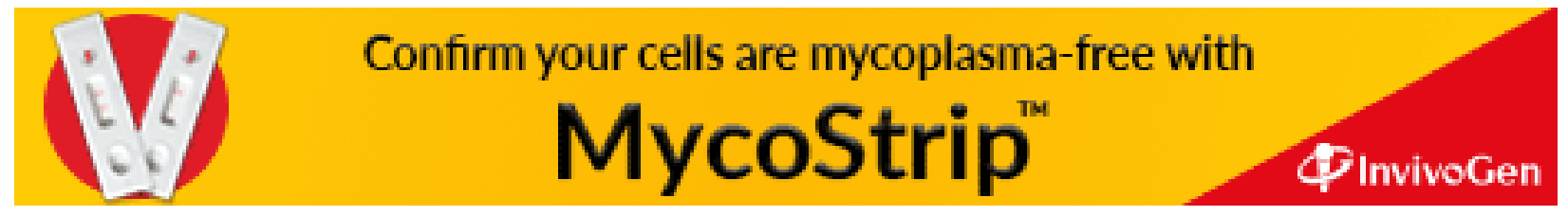

